\title{
Meliponini Neotropicais: o gênero Dolichotrigona Moure (Hymenoptera, Apidae, Apinae)
}

\author{
João M. F. Camargo ${ }^{1,2} \&$ Silvia R. M. Pedro ${ }^{1}$
}

\begin{abstract}
${ }^{1}$ Departamento de Biologia, Faculdade de Filosofia, Ciências e Letras de Ribeirão Preto, Universidade de São Paulo, Av. Bandeirantes, 3900, 14040-901, Ribeirão Preto-SP, Brasil.jmfdcama@usp.br / silviarmp@ffclrp.usp.br

${ }^{2}$ Pesquisador I do CNPq.
\end{abstract}

\begin{abstract}
Neotropical Meliponini: the genus Dolichotrigona Moure (Hymenoptera, Apidae, Apinae). The Neotropical stingless bees genus Dolichotrigona Moure, 1950, is revised. Seven new species are described: D. mendersoni sp. nov. (Brazil: AM, AC, RO), D. clavicornis sp. nov. (Brazil: AC), D. rondoni sp. nov. (Brazil: RO), D. tavaresi sp. nov. (Brazil: AM, AC), D. browni sp. nov. (Brazil: RO, AC, MT; Peru, Equador, Bolivia), D. moratoi sp. nov. (Brazil, AM, AC) and D. chachapoya sp. nov. (Peru). The holotype of Trigona martinezi Brèthes, 1920, and the lectotype of Melipona longitarsis Ducke, 1916 - herein designated -, were examined and redescribed. Trigona schulthessi Friese, 1900, was interpreted based on the literature. Identification key for species and illustrations of the main diagnostic characters are presented.
\end{abstract}

Keywords. Apidae; Dolichotrigona; Meliponini; stingless bees; taxonomy

Resumo. Meliponini Neotropicais: o gênero Dolichotrigona Moure (Hymenoptera, Apidae, Apinae). O gênero neotropical de abelhas-sem-ferrão Dolichotrigona Moure, 1950, é revisado. Sete espécies novas são descritas: D. mendersoni sp. nov. (Brasil: AM, AC, RO), D. clavicornis sp. nov. (Brasil: AC), D. rondoni sp. nov. (Brasil: RO), D. tavaresi sp. nov. (Brasil: AM, AC), D. browni sp. nov. (Brasil: RO, AC, MT; Peru, Equador, Bolívia), D. moratoi sp. nov. (Brasil, AM, AC) e D. chachapoya sp. nov. (Peru). O holótipo de Trigona martinezi Brèthes, 1920, e o lectótipo de Melipona longitarsis Ducke, 1916 - aqui designado -, foram examinados e redescritos. Trigona schulthessi Friese, 1900, foi interpretada com base na literatura. Chave para identificação das espécies e ilustrações dos principais caracteres diagnósticos são apresentadas.

Palavras-Chave. Abelhas-sem-ferrão; Apidae; Dolichotrigona; Meliponini; taxonomia.

Dolichotrigona Moure, 1950 é um gênero de abelhas-semferrão, sociais, muito pequenas, designadas, genericamente juntamente com as espécies de Trigonisca Moure, $1950-$, em algumas regiões do norte do Brasil, pelo nome de "lambeolhos", e na Costa Rica, "chupaojos" (Wille 1965). Na região do rio Xingu, centro-oeste do Brasil, são muito conhecidas, juntamente com as Trigonisca, pelo terrível incômodo que causam aos viajantes; chegam aos milhares e penetram no nariz e ouvidos, mas principalmente nos olhos, para coleta de secreções, e no suor; quando mortas, deixam uma secreção cáustica que causa irritação nos olhos (Carvalho et al. 1949; Villas-Bôas \& Villas-Bôas 1994). São conhecidas do México até a Amazônia. Dolichotrigona apresenta certas afinidades morfológicas com os gêneros Celetrigona Moure, 1950 e Trigonisca, ambos também da região Neotropical. Apenas duas espécies eram reconhecidas até agora para o gênero: $D$. schulthessi (Friese, 1900) e D. longitarsis (Ducke, 1916). O exame dos tipos de Melipona longitarsis e Trigona martinezi Brèthes, 1920, e a descoberta de algumas espécies novas, abriram a oportunidade de se estudar um pouco melhor o gênero, e os resultados são aqui apresentados, incluindo ilustrações para os principais caracteres, cartogramas com registros de ocorrência e chave para identificação das espécies.

\section{MATERIAL E MÉTODOS}

A maioria dos exemplares estudados está depositada na coleção do Departamento de Biologia da Faculdade de Filosofia, Ciências e Letras de Ribeirão Preto, Universidade de São Paulo (RPSP, coleção Camargo). Outras instituições e pesquisadores que forneceram material estão listadas a seguir: DZUP - Departamento de Zoologia, Universidade Federal do Paraná, Coleção Entomológica Pe. J. S. Moure, Curitiba, Paraná, Brasil (G. A. R. Melo); INHS - Illinois Natural History Survey, Insect Collection, Urbana-Champaign, Illinois, EUA (C. Favret / C. Rasmussen); INPA - Instituto Nacional de Pesquisas da Amazônia, Manaus, Amazonas, Brasil (J. A. Rafael / A. L. Enriques / M. L. Oliveira); ISNB - Institut Royal des Sciences Naturelles de Belgique, Bruxelas, Bélgica (A. Pauly / C. Rasmussen); MACN - Museo Argentino de Ciencias Naturales "Bernardino Rivadavia", Buenos Aires, Argentina (A. Roig Alsina); MPEG - Museu Paraense Emílio Goeldi, Belém, Pará, Brasil (W. Overal / O. T. Silveira); MUSM Coleccion del Departamento de Entomologia, Museo de Historia Natural, Universidad Nacional Mayor de San Marcos, Lima, Peru (G. Lamas / C. Rasmussen); SEMC - Snow Entomological Museum, University of Kansas, Lawrence, Kansas, EUA (R. Brooks, curador, na época).

Para a interpretação das espécies já descritas, foram examinados exemplares da série-tipo de $D$. longitarsis e designado o lectótipo; a interpretação de $D$. schulthessi foi feita com base na descrição de Friese (1900) e no estudo de espécimens coletados próximos da localidade do tipo. Também 
foi examinado o holótipo de Dolichotrigona martinezi (Brèthes, 1920), originariamente descrita no gênero Trigona, e cuja descrição deixava dúvidas quanto a sua subordinação genérica.

A terminologia empregada está de acordo com Pedro \& Camargo (2003). Tergos e esternos abdominais são indicados com TII-TVIII e EII-EVIII, respectivamente; o termo propódeo refere-se ao $1^{\circ}$ tergo abdominal incorporado ao tórax; o "disco propodeal" é denominado metaposnoto; as pernas são indicadas com numerais romanos - I, II, III; as asas são referidas apenas como anteriores e posteriores. Os flagelômeros da antena são indicados como $1^{\circ} \mathrm{fl}$., $2^{\circ} \mathrm{fl}$., etc. O escapo antenal é referidos apenas como escapo. A distância entre o álveolo antenal e o ocelo lateral é indicada como distância alveolocelar, e distância interocelar refere-se a distância entre os ocelos laterais. As medidas referentes aos flagelômeros foram tomadas considerando o diâmetro máximo. O diâmetro do escapo foi medido próximo à base. A medida de comprimento da asa anterior foi tomada entre o ápice do esclerito Costal e o ápice da asa, exceto quando indicada de outra forma. Todas as medidas são apresentadas em milímetros.

Os desenhos anatômicos foram feitos com auxílio de câmara clara acoplada ao estereomicroscópio LEICA MZ APO; as fotos foram feitas com câmera PENTAX MZ-M, acoplada ao mesmo estereomicroscópio.

Nas listas sinonímicas, o sinal de interrogação (“?”), na frente do nome do autor, significa que há dúvidas quanto à identidade da espécie.

Nas descrições das espécies, os caracteres comuns ao gênero não são mencionados.

No item "Material examinado", foram transcritos os dados das etiquetas de procedência e de todas as demais etiquetas adicionadas pelos autores precedentes, apenas foram padronizadas as indicações de meses (algarismos romanos, caixa alta) e anos (quatro algarismos). Países e subdivisões (estado, departamento, províncias, etc.) foram listados de oeste para leste e de norte para sul, conforme Zanella et al. (2000).

\section{Dolichotrigona Moure, 1950}

Hypotrigona (Dolichotrigona) Moure, 1950: 248

Espécie-tipo: Melipona longitarsis Ducke, 1916 (por designação original).

Dolichotrigona; Camargo \& Moure, 1988: 294

Por muito tempo, o nome Hypotrigona Cockerell, 1934, foi usado pelos principais autores na área da sistemática de abelhas (e.g. Schwarz 1938, 1940, 1948; Moure 1950) para se referirem àquelas abelhas sociais sem-ferrão muito pequenas, destituídas de estrias amarelas na cabeça e tórax, e com venação alar bastante reduzida, que ocorrem na África e nas regiões Indo-Malaia e Neotropical.

Dolichotrigona foi inicialmente proposto por Moure (1950) como um subgênero de Hypotrigona, assim como Leurotrigona Moure, 1950, Celetrigona e Trigonisca; nessa ocasião, Moure salientou as peculiaridades dessas pequenas abelhas neotropicais, mas ainda sem conhecer, "de visu", as espécies africanas e indo-malaias, para as quais Cockerell (1934) havia proposto o subgênero Hypotrigona, subordinado ao gênero Trigona Jurine, 1807. Moure não questionou a legitimidade de Hypotrigona como um grupamento natural, e chamou a atenção para o fato de que a grande extensão geográfica ocupada pelo gênero seria indicativa de sua antigüidade - "... um dos mais primitivos....", dentre os Meliponini. Ulteriormente, porém, ressaltou que as semelhanças entre as abelhas incluídas em Hypotrigona, presentes nos três continentes, poderiam ser resultantes de um processo de convergência em função do pequeno tamanho corporal, e o agrupamento não representaria uma "linhagem filogenética" (Moure 1951, 1961). Ainda, ao revisar as abelhas do Velho Mundo, Moure (1961) propôs os novos gêneros Pariotrigona e Lisotrigona, da região Indo-Malaia, e Liotrigona e Cleptotrigona [na ocasião, como Lestrimelitta (Cleptotrigona)], da região Etiópica, como unidades distintas e não diretamente relacionadas a Hypotrigona, restringindo este último nome a um pequeno grupo de espécies da região Etiópica. A formalização das "Hypotrigona neotropicais" como um grupamento distinto, vem aparecer nos trabalhos de Wille \& Chandler (1964: 191-192) e Wille (1979: 266-267), onde tratam Celetrigona, Dolichotrigona, Leurotrigona e Trigonisca, como uma unidade subgenérica sob a denominação geral de Trigona (Trigonisca). Essa proposta de arranjo taxonômico tem sido adotada formalmente por Michener (1990, 2000), que, todavia, elevou Trigonisca à categoria de gênero, considerando Celetrigona, Dolichotrigona e Leurotrigona como sinônimos juniores, principalmente com base em caracteres do gonóstilo das operárias, mas sem apresentar uma análise cladística formal. Silveira et al. (2002), sugerem que o nome Trigonisca seja usado para incluir apenas Celetrigona, Dolichotrigona e Trigonisca (s. str.), e dão tratamento de gênero para Leurotrigona.

O tratamento de Dolichotrigona como gênero foi sugerido primeiramente por Camargo \& Moure (1988), seguido por Camargo $(1988,1989)$ e Camargo \& Pedro (1992), e essa é a orientação que seguimos no presente trabalho.

Há suspeita de que Dolichotrigona e Trigonisca possam constituir um grupo monofilético (Camargo \& Moure 1988; Camargo 1989). Todavia, Trigonisca é um grupo bastante heterogêneo; p. ex., a célula marginal da asa anterior varia quanto à forma; enquanto que em algumas espécies é relativamente estreita, em outras é muito bojuda, praticamente idêntica àquela das espécies de Dolichotrigona. O número e a forma dos dentes da mandíbula também variam, exatamente como nas espécies de Dolichotrigona. Contudo, as possíveis relações filogenéticas entre esses dois grupos só podem ser melhor esclarecidas, talvez, quando houver machos em número suficiente para um estudo detalhado. Pela mesma razão não se apresenta uma hipótese de relações filogenéticas para as espécies de Dolichotrigona.

Embora conhecendo apenas uma espécie, $D$. longitarsis, a descrição do gênero apresentada por Moure (1950, 1951), na qual se baseia a diagnose a seguir, é bastante completa e detalhada, deixando pouco a ser acrescentado. 
a- Comprimento do corpo entre 2,8 e 4,0; largura da cabeça entre 1,3-1,5. b- Integumento micro-alveolado, mais forte e densamente na fronte (alvéolos com ca. 0,015 de diâmetro) e mesoscuto; reticulado nas genas, propódeo, tégulas, esternos, e superfície externa das mandíbulas; liso polido no tergo metassomal I, por inteiro, II-III, exceto margem apical e lados, e disco do IV. c- Corpo castanho-escuro até enegrecido. Membrana das asas hialina ou muito levemente tingida de ferrugíneo; veias acastanhadas. d- Desenhos amarelos ausentes na face e tórax, apenas a porção apical do último fl., e mandíbulas de algumas espécies, amareladas. e- Pilosidade predominantemente amarelo-palha; as cerdas mais longas e robustas na cabeça, mesoscuto e escutelo um pouco mais escuras, quase ferrugíneas, cerdas do penicilo e da superfície interna dos tarsos, ferrugíneas (ver item o); ventralmente, as cerdas mais finas e esbranquiçadas, muito longas, na região ventral dos mesepisternos tão longas quanto 3-5x o diâmetro do escapo, ou mais. Cerdas predominantemente simples, eretas, esparsas na face, fronte, vértice, mesoscuto, e nos tergos IIIVI mais abundantes nos lados, no bordo apical do escutelo mais longas; escapo, pedicelo, $1^{\circ} \mathrm{fl}$. e lados dos alvéolos antenais, com cerdas de tamanho variado, ou glabros, apenas com a micropilosidade decumbente. Pilosidade curta, decumbente, curto-plumosa, pouco densa, na face. Metaposnoto glabro; propódeo apenas com algumas cerdas simples, esparsas, nos lados e algumas cerdas plumosas, muito finas, ao redor do espiráculo. Margens anterior e posterior das tíbias III apenas com cerdas simples, muito longas, algumas, no terço apical da margem posterior, quase tão longas quanto a largura máxima da tíbia. $\mathbf{f}$-Cabeça ca. $1,15 x$ mais larga que longa, um pouco mais larga que o tórax; interorbital máxima um pouco maior ou igual ao comprimento do olho; órbitas internas dos olhos levemente sinuosas e convergentes embaixo, ou paralelas; tangente superior dos alvéolos antenais levemente abaixo do meio da face; vértice, arredondado. Área malar um pouco mais longa que o diâmetro do $2^{\circ} \mathrm{fl}$. Rebordo pré-occipital arredondado superiormente e formando uma carena fina e curta, revirada para fora, nas laterais; genas, vistas de perfil, um pouco mais largas que os olhos; órbitas externas contornadas por uma carena fina e baixa que demarca o limite do tegumento micro-alveolado, mate. g-Clípeo ca. $2 \mathrm{x}$ mais largo que longo, quase plano, aproximadamente trapezoidal; sutura epistomal, nos lados, levemente sinuosa e divergentes para o ápice; entre as suturas subantenais, fortemente arqueada para baixo, em semicírculo; as suturas subantenais praticamente nulas. h- Labro levemente biconvexo, com a depressão longitudinal mediana mais nítida em algumas espécies. i- Mandíbula com um ou dois dentículos, aproximadamente no terço interno da lâmina apical (Figs. 513). j-Escapo 0,9-1,2x tão longo quanto a distância alveolocelar, estreitado medianamente; pedicelo um pouco mais longo que o $1^{\circ}$ fl. (Figs. 14-23); o $2^{\circ}$ fl. ca. 1,5x mais longo que largo, subigual ao $1^{\circ} \mathrm{e} 3^{\circ}$; o pedicelo e fls. basais um pouco achatados, conferindo uma forma levemente clavada ao flagelo antenal, em vista dorsal. k- Pronoto tão longo quanto o escutelo, a margem anterior sem reentrância mediana, o sulco transversal pré-marginal muito raso, quase nulo. l- Escutelo curto, 2,12,5x mais longo que largo, levemente convexo, a margem posterior em semicírculo, um pouco revirada para baixo, recobrindo parcialmente o metanoto, em vista superior; sem fóvea basal. m- Asas anteriores (Fig. 37) mais curtas que o comprimento do corpo, e ca. $2 \mathrm{x}$ mais longas que a tíbia III, ultrapassando o ápice do abdômen em pouco menos de $1 / 4$ de seu comprimento. Pterostigma grande, ca. $2,7 \mathrm{x}$ a largura do $2^{\circ}$ fl. e 0,30 de seu próprio comprimento; R1 muito curta, ca. 1/6 do comprimento do pterostigma, como um apêndice deste. Célula marginal ca. 2,4-2,6x mais longa que larga, fortemente alargada na base e aberta no ápice. Bifurcação entre $\mathrm{Me} \mathrm{M}+\mathrm{Cu}$ posterior a cu-anal e deslocada para cima. Ângulo submarginal, entre Rs e Rs $+\mathrm{M}$, um pouco mais aberto que $90^{\circ}$. Ângulo entre $\mathrm{M}$ e Rs $+\mathrm{M}$, aberto, ca. $120^{\circ}$. Veia M ca. 0,7-0,8x mais curta que a $1^{\text {a }}$ abscissa da $\mathrm{Cu}$, e esta muito suavemente marcada (Fig. 37). Células submarginais nulas, apenas as células radial e cubital fechadas. Asas posteriores apenas com a veia A evidente. Lóbulo jugal um pouco mais curto que metade do comprimento do anal. Hâmulos, 5. n- Tíbia III subtriangular longa e estreita, ca. $4 \mathrm{x}$, ou um pouco menos, mais longa que larga, suave e gradualmente expandida em direção ao ápice, um pouco encurvada para trás, a margem anterior convexo-côncava, e a posterior suavemente encurvada com o terço apical quase reto, crenulada devido aos pontos pilígeros salientes (Fig. 38); o canto póstero-distal em ângulo agudo; margem apical sinuosa com uma projeção mediana forte, em semicírculo, na região do côndilo de articulação com o basitarso; corbícula fracamente côncava ocupando o terço apical. Superfície interna com a área quirotriquiada suavemente elevada; a faixa marginal posterior, glabra, formando uma rampa aproximadamente tão larga quanto a área quirotriquiada. Pente e penicilo normais. o- Basitarso III estreito, ca. $0,7 \mathrm{x}$ da largura da tíbia III, e $0,4 \mathrm{x}$ seu próprio comprimento, subretangular, de lados paralelos ou um pouco divergentes para o ápice (Fig. 38 ); o canto póstero-distal em ângulo agudo ou reto. Face interna sem área basal sedosa, o revestimento cerdoso arranjado em 8-9 fileiras transversais de cerdas bem regulares (semelhante ao rastelo de Apis mellifera Linnaeus, 1758), aumentando em comprimento em direção ao ápice do basitarso. p- Metaposnoto + propódeo relativamente protuberante; o disco basal em declive de ca. $40^{\circ}$ e o terço posterior vertical. qAbdômen curto e largo, aproximadamente em forma de ogiva.

As espécies do gênero Dolichotrigona podem ser reconhecidas dentre os demais Meliponini pela combinação dos seguintes caracteres: integumento opaco, micro-alveolado, ausência de estrias amarelas na cabeça e tórax, comprimento do escapo entre 0,9 e 1,2x a distância alveolocelar, fls. 1-3 mais longos que largos, o flagelo um pouco achatado próximo à base, mandíbula com um ou dois dentículos, sendo o dentículo mediano um pouco projetado além do bordo apical, célula marginal fortemente alargada na base e aberta no ápice (Fig. 37), tíbia III muito longa e estreita, com o bordo posterior crenulado na inserção das cerdas (Fig. 38). Dentre as "Hypotrigona" neotropicais assemelha-se mais a Celetrigona, 
da qual distingue-se pelo labro sem tubérculos, apenas levemente biconvexo, integumento opaco, densamente microalveolado, célula marginal mais larga na base, curta e mais aberta no ápice e ausência de manchas amarelas no clípeo e face; Leurotrigona apresenta, entre outros caracteres, integumento liso polido, escapo mais curto que a distância alveolocelar, e fls. 1-3 mais largos que longos e cilíndricos; em Trigonisca, a tíbia III mais curta e larga (menos de $3 \mathrm{x}$ mais longa que larga), o escapo e fls. 1-3, mais curtos e menos achatados.

Chave para as espécies de Dolichotrigona (operárias)

1. Mandíbula com um dente, o canto interno arredondado (Figs. 5-8). Área parocular inferior com cerdas eretas, curtas, finas, não maiores que o diâmetro do escapo (Fig. 24), pouco distintas da pilosidade curtadecumbente, ou ausentes (Fig. 25); cerdas do escapo delgadas e mais curtas que o diâmetro deste (Figs. 1416, 18), ou ausentes (Fig. 17) .......................................... 2

Mandíbula com dois dentes; o dente do canto interno bem desenvolvido (Figs. 10-13), ou ao menos o canto interno anguloso (Fig. 9). Área parocular inferior com cerdas eretas, longas, grossas, sobressaindo à pilosidade curta-decumbente (Figs. 26-29); cerdas do escapo robustas e mais longas que o diâmetro deste ao menos algumas na parte basal (Figs. 19-23) (exceto um exemplar de Cáceres, MT, onde são mais curtas; veja item "Variação" em D. browni sp. nov.) ... 6

2(1). Cerdas eretas ausentes no escapo (Fig. 17), face (exceto minúsculas cerdas no clípeo e área supra-clipeal; Figs. 25,31 ), disco do mesoscuto e do escutelo, e mesepisternos. Labro com depressão mediana longitudinal acentuada. Brasil, AM (região do médio e alto Purus), leste do Acre, e extremo oeste de Rondônia (Fig. 44) ..................................... D. mendersoni sp. nov. Com cerdas eretas no escapo (Figs. 14-16, 18), face (como na Fig. 24), mesoscuto, disco do escutelo e mesepisternos. Labro com suave depressão mediana longitudinal 3

3(2). Cerdas da margem posterior do escutelo longas, entre ca. 1,3-1,6x o comprimento deste. Escapo longo, ca. 1,1-1,2x a distância alveolocelar. Asas levemente ferrugíneas. Mandíbulas geralmente amareladas ....... 4

Cerdas da margem posterior do escutelo aproximadamente tão longas quanto o comprimento deste, $0,9-1,1 \mathrm{x}$. Comprimento do escapo igualando à distância alveolocelar, ou um pouco mais curto. Asas hialinas. Mandíbulas enegrecidas ou ferrugíneo-fuscas

4(3). Escapo dilatado no terço apical (Fig. 18) e muito longo, ca. 1,2x a distância alveolocelar. Cerdas da margem posterior do escutelo muito longas, ca. 1,5-1,6x o comprimento deste. Olhos âmbar-avermelhados. Brasil, AC (Fig. 44) ................................ D. clavicornis sp. nov.

Escapo normal, apenas levemente alargado próximo ao ápice (Fig. 14) e moderadamente longo, ca. 1,1x a distância alveolocelar. Cerdas da margem posterior do escutelo longas, ca. 1,3x o comprimento deste. Olhos âmbar-amarronzados. Brasil, PA, MA, AM, AC, RO, MT e Guiana Francesa (Fig. 44) ........ D. longitarsis (Ducke)

5(3). Escapo tão longo quanto a distância alveolocelar. Veia $\mathrm{M}$ da asa anterior levemente curva (como na Fig. 37). México, Guatemala, Honduras, Costa Rica, Panamá, Colômbia (Fig. 44) ......................... D. schulthessi (Friese)

Escapo levemente mais curto $(0,94 \mathrm{x})$ que a distância alveolocelar. Veia $\mathrm{M}$ da asa anterior quase reta. Peru, Lima (?, veja item "Discussão" em D. martinezi; Fig. 44) D. martinezi (Brèthes)

6(1). Escapo curvado no ápice; $1^{\circ}$ fl. curto, ca. metade de sua largura (Fig. 23); linha frontal nitidamente rebaixada, deixando as duas áreas discais da fronte bastante proeminentes (Fig. 36). Peru (Fig. 44) ...

D. chachapoya sp. nov.

Escapo normal, não curvado no ápice; $1^{\circ} \mathrm{fl}$. aproximadamente tão longo quanto largo (Figs. 19-22); linha frontal normal, apenas levemente rebaixada (Figs. 33-35) 7

7(6). Dente do canto interno da mandíbula pouco conspícuo, ou o canto apenas com uma leve reentrância (Fig. 9). Primeiro fl. com cerdas eretas relativamente longas e robustas, tão longas quanto o diâmetro do artículo, ou mais (Fig. 19). Brasil, RO (Fig. 44) .... D. rondoni sp. nov. Dente do canto interno da mandíbula, conspícuo (Figs. 10-12). Cerdas do $1^{\circ} \mathrm{fl}$. variáveis ou ausentes ............. 8

8(7). Cerdas do escapo não mais longas que $2 \mathrm{x}$ o diâmetro deste e de comprimento mais ou menos uniforme ao longo de todo o escapo (Fig. 20). Primeiro fl. sem cerdas eretas, ou apenas com 1-2 cerdinhas eretas muito curtas, não mais que metade do diâmetro do artículo; último fl. por inteiro, ou predominantemente amarelo. Dente do canto interno da mandíbula relativamente curto (Fig. 10). Brasil, região do rio Ipixuna, AM e oeste do Acre (Fig. 44) D. tavaresi sp. nov.

Cerdas do escapo, longas, mais que 2x o diâmetro deste, principalmente as da parte basal; $1^{\circ} \mathrm{fl}$. com ou sem cerdas eretas (Figs. 21, 22); último fl. de cor variável. Dente do canto interno da mandíbula bem desenvolvido e pontiagudo (Figs. 11, 12) ... 9

9(8). Cerdas eretas, longas, apenas na metade basal do escapo, as mais longas com ca. 2x o diâmetro deste (Fig. 21; exceto exemplar de Cáceres, ver item "Discussão"); pedicelo com cerdas eretas curtas, menores que o diâmetro deste; $1^{\circ}$ fl. com cerdas eretas muito curtas, 
até ca. metade do diâmetro deste, ou ausentes; último fl. apenas com o ápice amarelado, ou por inteiro enegrecido. Brasil, AC, RO, MT, Bolívia, Peru e Equador (Fig. 44) D. browni sp. nov.

Cerdas eretas, longas, em todo o escapo, as mais longas, na parte basal, com ca. 3x ou mais o diâmetro deste; pedicelo e $1^{\circ}$ fl. com cerdas eretas longas, ca. 1,0-1,5x o diâmetro dos respectivos artículos (Fig. 22); último fl. por inteiro amarelo, e às vezes também o penúltimo; Brasil, AC, AM (Fig. 44) D. moratoi $\mathbf{s p . ~ n o v . ~}$

Dolichotrigona longitarsis (Ducke, 1916)

(Figs. 1, 2, 5, 14, 24, 37, 38, 44; Tabela I)

Melipona longitarsis Ducke, 1916: 88, 82, 90, fig. 25a; Ducke, 1925: 342, 348, 361; Nascimento, 1979: 6 ("Lectoparátipo").

Trigona longitarsis; Schwarz, 1932: 244; Michener, 1997: 21.

Hypotrigona longitarsis; Moure, 1944: 71.

Hypotrigona (Dolichotrigona) longitarsis; Moure, 1950: 248, 251, 253.

Dolichotrigona longitarsis; ?Camargo, 1988: 356; ?Oliveira \& Morato, 1994: 291.

Trigonisca longitarsis; Michener, 1990: 131, 132, 146; Michener, 1999: 71 (fig. 8); Michener, 2000: 789 (fig. 118-11,C), 804, 805; Roubik, 1992: 518 (como sin. de D. schulthessi); Silveira et al., 2002: 92. Trigonisca (Dolichotrigona) longitarsis; Michener \& Roubik, 1993: 256; Ayala, 1999: 114 (como sin. de D. schulthessi).

Diagnose. Operária. Largura da cabeça entre 1,36-1,47, comprimento da asa anterior entre 2,64-2,85; mandíbula com 1 dentículo (Fig. 5); escapo normal (Fig. 14), ca. 1,1x mais longo que a distância alveolocelar; $1^{\circ}$ fl. longo, comprimento aproximadamente igual à sua largura (Fig. 14); cerdas do escapo mais curtas que o diâmetro deste (Fig. 14); pedicelo e $1^{\circ}$ fl. com cerdas curtas, menores que o diâmetro destes (Fig. 14); área parocular inferior com cerdas eretas curtas, ca. metade do diâmetro do $2^{\circ} \mathrm{f}$ l. (Fig. 24); cerdas do bordo posterior do escutelo ca. 1,3x mais longas que o comprimento deste; membrana das asas levemente tingida de ferrugíneo.

\section{Lectótipo, operária (Figs. 1, 2; Tabela I).}

Dimensões. Comprimento total aproximado, 3,60; da asa anterior, ca. 2,67 (incluindo a tégula, ca. 3,03); largura da cabeça, 1,37 ; do TIII, 1,00 .

Cor do integumento. Preto (um pouco descolorido devido às condições de conservação); base do escapo, metade apical do último fl., área malar, mandíbula e pernas II e III, um pouco mais claras; margem e área discal da tégula, e margem dos TIIITVI, translúcidas. Membrana das asas levemente tingida de ferrugíneo (cobertas por hifas secas de fungos); microtríquias castanhas; veias méleas.

Pilosidade. Na maior parte, perdida; apenas algumas cerdas amarelo-palha no labro, vértice, região ântero-ventral dos mesepisternos, parte do mesoscuto, região ventral do tórax e abdômen, e pernas. Cerdas eretas no $1^{\circ} \mathrm{fl}$., faltando; no pedicelo uma única cerda muito curta, 0,03. Face apenas com microcerdas plumosas, decumbentes, quase imperceptíveis. No vértice apenas algumas cerdas eretas inteiras, 0,06 ; na região anterior dos mesepisternos, 0,04; na porção anterior do mesoscuto, 0,05 .

Integumento. Como descrito para o gênero.

Forma e proporções (medidas na Tabela I). Cabeça 1,12x mais larga que longa e 1,25x mais larga que a distância clipeocelar. Olhos 2,37x mais longos que largos, levemente convergentes embaixo. Área malar 1,33x mais longa que o diâmetro máximo do $2^{\circ} \mathrm{fl}$. Clípeo $0,42 \mathrm{x}$ mais curto que sua largura máxima e $0,25 \mathrm{x}$ a distância clipeocelar. Mandíbulas $0,55 \mathrm{x}$ a distância clipeocelar; com um dentículo no terço interno. Labro uniformemente convexo, apenas com uma leve depressão mediana longitudinal. Escapo 1,09x mais longo que a distância alveolocelar, um pouco achatado medianamente (Fig. 14). O $1^{\circ}$ fl. tão longo quanto largo (Fig. 14). Distância interocelar 1,09x maior que a ocelorbital e $2,27 \mathrm{x}$ o diâmetro do ocelo médio. Escutelo e pernas III perdidos. Asa anterior parcialmente rasgada. Veia M levemente curvada (como na Fig. 37).

Variação. Alguns exemplares de Rondônia apresentam mandíbulas um pouco mais escuras. O exemplar de Manaus Manacapuru, AM, apresenta, no clípeo, uma faixa pré-apical ferrugínea-clara. Os exemplares de Manaus (Tarumã Mirim), Itacoatiara e o lectótipo do rio Mapuera, Trombetas, são um pouco menores (largura da cabeça, 1,36-1,39) que aqueles de outras localidades $(1,40-1,47)$.

Material-tipo. Lectótipo, operária, aqui designado, de "R. Mapuera (Trombetas), 10.12.1907 Ducke" [etiq. manuscrita], "Brazil Estado do Pará" [etiq. impressa], depositado no Museu Paraense Emílio Goeldi (MPEG). Este mesmo exemplar foi designado como "Lectoparátipo" por Moure \& Michener, 1955, de acordo com Nascimento (1979: 6); contém, além das etiquetas acima mencionadas, as seguintes: "Melipona longitarsis Ducke Lectoparatypus" [manuscrita com tinta vermelha] e "Hymenoptera Apocrita Aculeata: Apoidea: Meliponinae: Meliponini: Melipona longitarsis Reorganizado 5.XII.1998" [etiq. impressa]. Este exemplar encontra-se bastante danificado, com a cor do integumento avermelhada, recoberto com hifas secas de fungos, faltando o par de asas do lado direito e as pernas posteriores, com uma enorme perfuração no tórax, atingindo quase todo o mesoscuto, escutelo e a lateral do mesepisterno direito, e quase toda a pilosidade foi perdida (Figs. 1, 2). A designação desse exemplar como lectótipo foi feita considerando que não se encontrou nenhum outro espécimen, da série original de Ducke, que tenha sido marcado como tipo por Moure e Michener (conforme Nascimento 1979: 6). Outros 4 exemplares, também depositados no MPEG, e considerados como pertencentes à série-tipo, visto que constam da relação de Ducke (1916: 89) e portam suas etiquetas originais de procedência, são considerados paralectótipos; todavia, a identificação destes não é segura, visto que se encontram, todos, muito danificados: - 1 op. de "R. Tapajós, Itaituba, 23.8.1902 Ducke", "Brazil Estado do Pará" [falta a cabeça, a perna I direita, as pernas III e o abdômen]; - 1 op. "I. Marajó, R. Anajás, 9.6.1900, Ducke", "Brazil Estado do Pará" [falta a cabeça, o par de pernas I, e a asa anterior direita um pouco danificada]; - 1 op. de "S. Antonio do Içá, 27.8.1906, Ducke", "Brazil Estado do Amazonas" [falta a cabeça, o par de pernas I, e os tarsômeros da perna III esquerda]; - 1 op. de "Barcellos 15-VI1905 Ducke", "Brazil Estado do Amazonas" [falta a cabeça e o par de pernas I]. 
Material examinado. GUIANA FRANCESA. Saint-Laurent $\boldsymbol{d} \boldsymbol{u}$ Moroni: Saül, 7 km N, Les Eaux Claires, 3³9'46"N, 5313'19"W, 220m, 4.VI.1997, J. Ashe, R. Brooks, FG1AB97 150, SM0103185 (1 op., SEMC). BRASIL. Amazonas: Fonte Boa, SA-19, 66-3f.xii, 2425.I.1977, Camargo, M. Mazucato (4 ops., RPSP); Itacoatiara, Faz. Aruanã, AM-010, Km 215, 17-18.XI.1990, F. J. A. Peralta (1 op., INPA); Manaus, Tarumã Mirim, 21.X.1980, F. J. A. Peralta (4 ops., INPA); Manaus - Manacapuru, Km 51, Faz. São Francisco, 0,5 Km S do Hotel, 12.II.1995, J. Lobo (1 op., RPSP); Maraã, 65'35' W, 153'S, 15-19.VIII.1993, Camargo, Pedro, Mazucato (1 op., 935607, RPSP); Rio Caiarí [= Uaupés?], foz do (Rio Negro), 15-20. IX.1952, Th. Dobzhansky (1 op., DZUP); Tapurucuara-Mirim, rio Negro, 66 $24^{\prime}$ 'W, 0 ${ }^{\circ} 25^{\prime}$ 'S, 01-04.VII.1999, Camargo, Pedro, Mazucato (1 op., 994498, RPSP); Tefé, I.1962, E. Carvalho (1 op., DZUP). Pará: Óbidos, XI.1954, F. M. Oliveira (1 op., DZUP); ibidem, idem, I.1962, (2 ops., DZUP); Rio Trairão, 50 Km NE Gradaús, SB-22, 514'' W, 7²1'S, 21-24.VII.1979, Mazucato (2 ops., RPSP). Acre: Rio Branco, Reserva Catuaba, 12.VIII.1993, M. L. Oliveira (1 op., INPA); ibidem, 21.V.1990, L. A. O. Campos (1 op., 000261, RPSP). Rondônia: Buritis, oeste de Buritis, $10^{\circ} 9^{\prime} 7^{\prime \prime S}$, 635' $41.5^{\prime \prime} \mathrm{W}, 10 . \mathrm{IX} .1997$, Brown, Boina, Vieira (2 ops., RO-14429, 14440, RPSP); Campo Novo, estrada C.N.-Buritis, 10²3'32.2"S, 63'39'25.6"W, 10.IX.1997, Brown, Boina, Vieira (4 ops., RO-14521, 14522, 14524, 14529, RPSP); ibidem, idem, BR-421/Rio Jaci-Paraná, $10^{\circ} 26^{\prime} 13,0$ "S, 6407'36,1"W, 11.IX.1997 (6 ops., RO-14210, 14211, 14216, 14242, 14247, 14266, RPSP); ibidem, idem, BR-421 oeste de C.N., $10^{\circ} 27^{\prime} 6.1^{\prime \prime S}, 63^{\circ} 51^{\prime} 52.8^{\prime \prime} \mathrm{W}$, 11.IX.1997 (1 op., RO-14301, RPSP); Costa Marques / GuajaráMirim, $12^{\circ} 1.486^{\prime}$ S, $64^{\circ} 18.084^{\prime} \mathrm{W}, 24 . X I .1996$, Brown, Boina, Vieira (8 ops., RO-3892, 3914, 3918, 3920-21, 3924, 3927-28, RPSP); Cujubim, Linha C2, $09^{\circ} 23.205^{\prime} \mathrm{S}, 6^{\circ} 34.854^{\prime \prime W}$, 25.III.1997, Brown, Boina, Vieira (1 op., RO-7168, RPSP); Guajará-Mirim, 10¹9.434'S, 64³3.849'W, 11.IX.1996, Brown, Boina, Vieira (6 ops., 1485, 1503, $1507,1509-10,1518$, RPSP); ibidem, idem, $10^{\circ} 50.408^{\prime} \mathrm{S}$, 64 ${ }^{\circ} 57.756^{\prime}$ 'W, 07.X.1996 (1 op., 1612, RPSP); ibidem, idem, $10^{\circ} 49.464^{\prime} \mathrm{S}, 64^{\circ} 54.282^{\prime} \mathrm{W}, 09 . X .1996$ (8 ops., 1784, 1797-98, 180002, 1804-05, RPSP); ibidem, idem, $10^{\circ} 45.516^{\prime} \mathrm{S}, 6^{\circ} 42.761^{\prime} \mathrm{W}$, 09.X.1996 (3 ops., 1815, 1889, 1899, RPSP); ibidem, idem, S1045.519', W6441.989', 10.X.1996 (3 ops., 1966, 1974, 1977, RPSP); ibidem, idem, 1045.683'S, 64²4.519' W, 11.X.1996 (1 op., 2108, RPSP); Jaru, $11^{\circ} 2.465^{\prime} \mathrm{S}, 62^{\circ} 54.239^{\prime} \mathrm{W}, 18 . X I I .1996$, Brown, Boina, Vieira (1 op., 4271, RPSP); Machadinho, 9²6.948'S, $61^{\circ} 51.445^{\prime} \mathrm{W}, 21 . I I I .1997$, Brown, Boina, Vieira (1 op., RO-6514, RPSP); Mirante da Serra, $10^{\circ} 56.284^{\prime}$ 'S, $62^{\circ} 42.425^{\prime}$ W, 31.I.1997, Brown, Boina, Vieira (1 op., 5199, RPSP); ibidem, idem, Fazenda Urupá, 11²’44.7"S, 62³4’41.8"W, 11.VI.1997 (2 ops., RO-11004, 11011, RPSP); Nova Califórnia, Linha Pioneiros, 947'56.7"S, 66'36'10.7"W, 25.VI.1997, Brown, Boina, Vieira (1 op., RO-11165, RPSP); Nova Mamoré, 1049.464'S, 64⒌282'W, 09.X.1996, Brown, Boina, Vieira (1 op., 1803, RPSP); Nova União, $10^{\circ} 52^{\prime} .080^{\prime}$ 'S, $62^{\circ} 27.955^{\prime} \mathrm{W}, 20 . X I I .1996$, Brown, Boina, Vieira (1 op., 4491, RPSP); ibidem, idem, $10^{\circ} 51.788^{\prime} \mathrm{S}, 62^{\circ} 23.348^{\prime} \mathrm{W}$, 08.III.1997 (1 op., 6203, RPSP); Ouro Preto D'Oeste, 21.VIII.1987, C. Elias, Projeto Polonoroeste (2 ops., DZUP); ibidem, idem 24.VIII.1987 (2 ops., DZUP); ibidem, idem, 03.IX.1987 (8 ops., DZUP); ibidem, idem, 22.IX.1987 (2 ops., DZUP); ibidem, idem, 13.XI.1987 (1 op., DZUP); Pimenta Bueno, XI.1960, M. Alvarenga (2 ops., DZUP; 1 op., 43.116, INHS; 1 op., RPSP); Pimenteiras, $13^{\circ} 14.366^{\prime}$ 'S, $60^{\circ} 50.462^{\prime} \mathrm{W}$, 24.II.1997, Brown, Boina, Vieira (1 op., 5398, RPSP); Porto Velho, Estação Ecológica Cuniã, 8²3’34.0"S, 6332’1.9"W, 22.V.1997, Brown, Boina, Vieira (4 ops., RO-9643-44, 9646, 9650, RPSP). Maranhão: Imperatriz, 5.VIII.1949, Dobzhansky (1 op., DZUP); Santa Helena, Alto Turi, 18.VIII.1965, Carq. \& Ed. (1 op., INPA). Mato Grosso: Nhambiquara, XI.1960, M. Alvarenga (3 ops., DZUP).

Distribuição geográfica e hábitat. Guiana Francesa e do oeste da Amazônia brasileira até o Maranhão (Fig. 44). Ducke (1916) menciona ter visto exemplares de Caquetá, Colômbia e

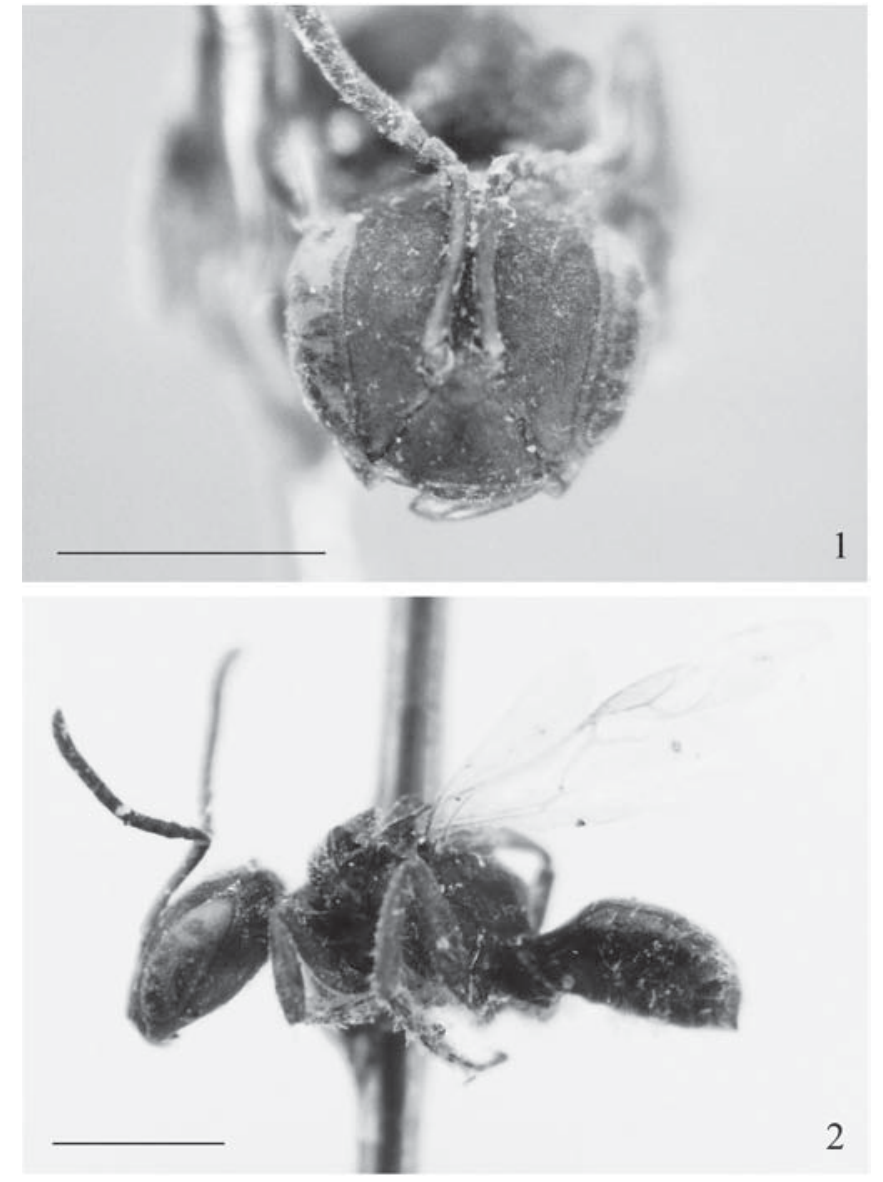

Figs. 1-2. Dolichotrigona longitarsis, lectótipo. Escalas $=1,0 \mathrm{~mm}$.

Iquitos, Peru, e Camargo (1988) relaciona 3 exemplares de "Mapiri, Bolívia", todavia, a identidade destes é duvidosa.

Nidificação. Desconhecida.

Discussão. Dolichotrigona longitarsis assemelha-se mais às espécies com um único dente na mandíbula, $D$. schulthessi, $D$. martinezi e D. clavicornis sp. nov. (Figs. 5, 6, 8), com as quais compartilha também a presença de cerdas curtas no escapo e face (Figs. 14, 15, 16, 18, 24). De D. schulthessi e $D$. martinezi distingue-se pelo escapo mais longo que a distância alveolocelar, pelas asas levemente ferrugíneas e pelas cerdas da margem posterior do escutelo mais longas que o comprimento deste; de $D$. clavicornis $\mathbf{s p . ~ n o v . ~ s e p a r a - s e ~ p e l a ~}$ forma do escapo - nesta é bastante dilatado no terço apical (Fig. 18) -, e pelas cerdas do escutelo, ca. 1,3x o comprimento deste; em D. clavicornis sp. nov., ca. 1,6x. A outra espécie que também apresenta um único dente na mandíbula é $D$. mendersoni sp. nov., esta, porém, não apresenta cerdas eretas no escapo, face (Figs. 17, 25), mesepisternos, etc.

A variação no tamanho dos exemplares interpretados como D. longitarsis e a ampla distribuição, sugere que pode haver mais de uma espécie incluída. 
Dolichotrigona martinezi (Brèthes, 1920) comb. nov. (Figs. 3, 4, 15, 44; Tabela I)

Trigona Martinezi Brèthes, 1920: 53.

Diagnose. Operária. Largura da cabeça, 1,39, comprimento da asa anterior, 3,15; mandíbula com 1 dentículo; escapo normal (Fig. 15), ca. 0,94x a distância alveolocelar; $1^{\circ}$ fl. longo, comprimento aproximadamente $0,7 \mathrm{x}$ sua largura (Fig. 15); cerdas do escapo mais curtas que o diâmetro deste (Fig. 15); pedicelo e $1^{\circ} \mathrm{fl}$. com cerdas curtas, menores que o diâmetro destes (Fig. 15); área parocular inferior com cerdas eretas curtas, ca. metade do diâmetro do $2^{\circ}$ fl. (como na Fig. 24); cerdas do bordo posterior do escutelo aproximadamente tão longas quanto o comprimento deste; membrana das asas hialina; veia $\mathrm{M}$ aproximadamente reta.

Holótipo, operária, redescrição (Figs. 3, 4, 15; Tabela I).

Dimensões. Comprimento total aproximado, 3,23; da asa anterior, 3,15 (incluindo a tégula, 3,45); largura da cabeça, 1,39; TIII, amassado.

Cor do integumento. Preto, castanho-escuros os tarsômeros, basitarsos e tíbias; castanho-amarelados as mandíbulas, exceto côndilos, que são pretos, e labro; escapo amarelado na base e gradualmente escurecido para o ápice na face dorsal; terço distal do último fl., amarelado. Clípeo, área supra-clipeal e paroculares inferiores, marrom-enegrecidos, deixando uma faixa negra acompanhando a sutura epistomal e na margem distal do clípeo. Membrana das asas, hialina; veias méleas, inclusive o pterostigma.

Pilosidade. Branco-palha em todo o corpo. Escapo com cerdas pequenas, eretas, um pouco maiores para o ápice, as mais longas igualando à metade do diâmetro deste; no pedicelo, 3-4 cerdinhas eretas, e no $1^{\circ} \mathrm{fl}$., 1-2, iguais, em comprimento, àquelas do escapo. Clípeo com algumas cerdas eretas, delgadas e esparsas, mais densas na área supra-clipeal, as mais longas ca. $1,1 \mathrm{x}$ o diâmetro do $2^{\circ} \mathrm{fl}$; ; cerdas eretas simples ausentes nas áreas paroculares inferiores, apenas as microcerdas plumosas semidecumbentes. Na fronte, as cerdas eretas aumentando gradualmente de tamanho em direção ao vértice, as mais longas, entre os ocelos, ca. 2,43x o diâmetro do escapo; entre os ocelos e as órbitas, iguais ao diâmetro do escapo. No mesoscuto, cerdas eretas esparsas, as mais longas ca. 1,57x o diâmetro do escapo; no escutelo, tão longas quanto o comprimento deste. Na tíbia III, as mais longas ca. $4 x$ o diâmetro do escapo. Parte anterior do mesepisterno com cerdas eretas com ca. 1,29x o diâmetro do escapo, e na parte inferior muito abundantes e longas, ca. 3x o diâmetro deste. (tergos, como na descrição para o gênero).

Integumento. Como descrito para o gênero.

Forma e proporções (medidas na Tabela I). Cabeça 1,09x

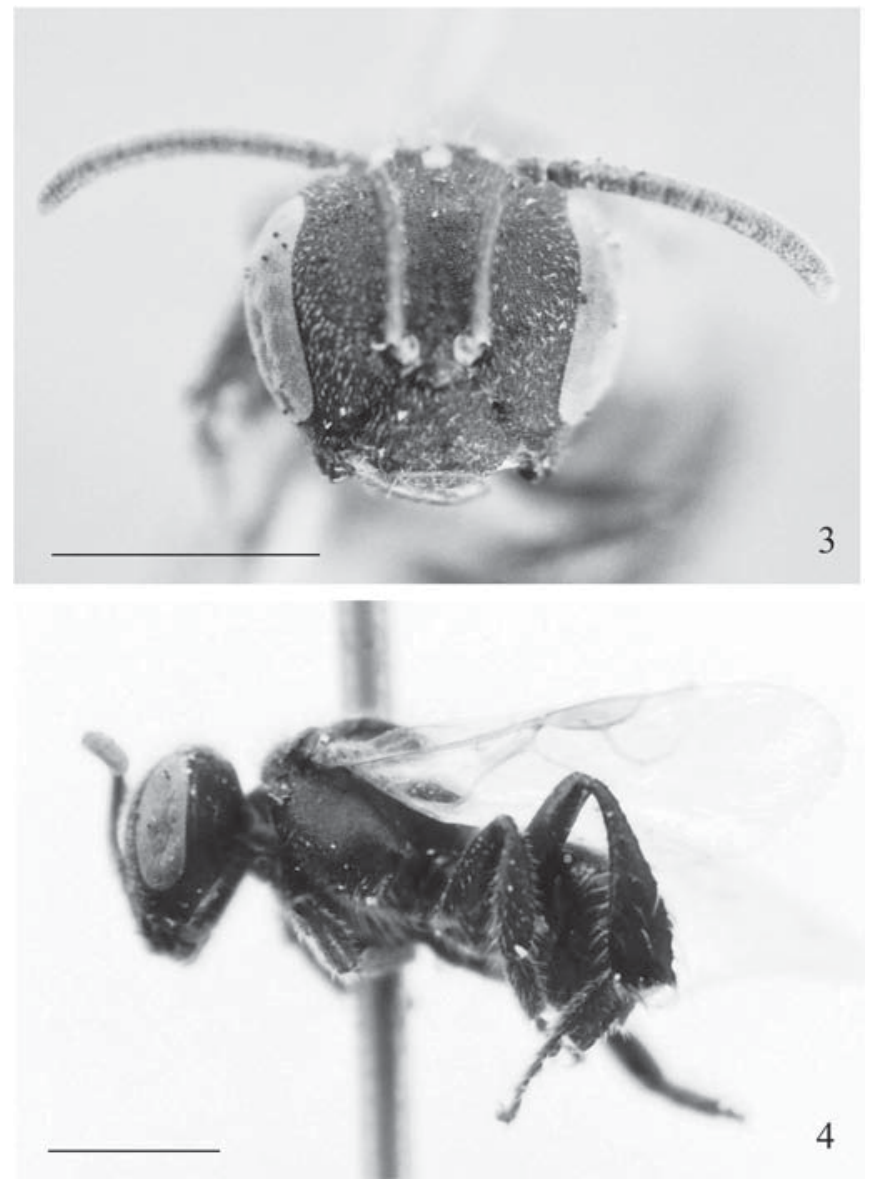

Figs. 3-4. Dolichotrigona martinezi, holótipo. Escalas $=1,0 \mathrm{~mm}$.

mais larga que longa e 1,23x mais larga que a distância clipeocelar. Olhos 2,38x mais longos que largos, levemente convergentes embaixo. Área malar 1,5x mais longa que o diâmetro máximo do $2^{\circ} \mathrm{fl}$. Clípeo $0,47 \mathrm{x}$ mais curto que sua largura máxima e $0,29 x$ a distância clipeocelar. Mandíbulas $0,68 x$ a distância clipeocelar, com um só dentículo aproximadamente no terço interno do bordo apical. Labro levemente biconvexo, com leve depressão mediana. Escapo curto, $0,94 \mathrm{x}$ a distância alveolocelar, cilíndrico e levemente alargado para o ápice (Fig. 15). $\mathrm{O} 1^{\circ} \mathrm{fl}$. pouco mais curto que largo, $0,72 \mathrm{x}$ (Fig. 15). Distância interocelar 1,04x maior que a ocelorbital e 2,45x o diâmetro do ocelo médio. Escutelo 2,19x mais largo que longo. Tíbia III quase tão longa quanto a largura da cabeça e $3,61 \mathrm{x}$ sua própria largura. Basitarso III 2,04x mais longo que largo; canto pósterodistal reto. Asa anterior aproximadamente 2,63x mais longa que larga e 2,27x mais longa que a largura da cabeça. Veia $\mathrm{M}$ quase reta e 1,15x mais longa que Rs $+\mathrm{M}$ (até o ponto onde recebe a $1^{\text {a }}$ recorrente).

Material-tipo. Holótipo, operária, com as seguintes etiquetas manuscritas: "8", "Lima, E. Martinez, 11. 1919", "Type!", "Trigona martinezi Brèthes"; impressas: "HOLOTYPUS" (vermelha), "Col. J. Brèthes", depositado no MACN. 
Tabela I. Medidas (mm) dos tipos, operárias, de Dolichotrigona longitarsis (Ducke, 1916), D. martinezi (Brèthes, 1920), D. mendersoni sp. nov., D. clavicornis sp. nov. e D. rondoni sp. nov. (* medidas aproximadas; ** medidas tomadas no parátipo de Extrema, RO, $\mathrm{n}^{\circ} 11363$ ).

\begin{tabular}{|c|c|c|c|c|c|}
\hline Medidas (mm) & D. longitarsis & D. martinezi & D. mendersoni & D. clavicornis & D. rondoni \\
\hline Comprimento total aproximado & 3,60 & 3,23 & 2,88 & 2,67 & 2,76 \\
\hline Largura máxima da cabeça & 1,37 & 1,39 & 1,40 & 1,50 & 1,35 \\
\hline Comprimento da cabeça & 1,22 & 1,28 & 1,28 & 1,34 & 1,18 \\
\hline Comprimento do olho & 0,90 & 0,86 & 0,94 & 0,90 & 0,86 \\
\hline Largura do olho & 0,38 & 0,36 & 0,40 & 0,41 & 0,40 \\
\hline Distância interorbital superior & 0,86 & 0,94 & 0,84 & 0,96 & 0,82 \\
\hline Distância interorbital máxima & 0,94 & 1,02 & 0,94 & 1,07 & 0,92 \\
\hline Distância interorbital inferior & 0,83 & 0,89 & 0,81 & 0,93 & 0,78 \\
\hline Diâmetro do ocelo médio & 0,11 & 0,11 & 0,12 & 0,12 & 0,11 \\
\hline Distância entre os ocelos laterais & 0,25 & 0,27 & 0,26 & 0,30 & 0,24 \\
\hline Distância ocelorbital (ocelo lateral) & 0,23 & 0,26 & 0,21 & 0,26 & 0,22 \\
\hline Distância interalveolar & 0,11 & 0,11 & 0,10 & 0,11 & 0,08 \\
\hline Distância alveolorbital & 0,26 & 0,30 & 0,27 & 0,31 & 0,26 \\
\hline Distância alvéolo-ocelo lateral & 0,66 & 0,71 & 0,69 & 0,71 & 0,64 \\
\hline Diâmetro do alvéolo & 0,13 & 0,14 & 0,13 & 0,14 & 0,12 \\
\hline Comprimento do clípeo & 0,27 & 0,33 & 0,32 & 0,35 & 0,28 \\
\hline Largura máxima do clípeo & 0,64 & 0,71 & 0,65 & 0,72 & 0,60 \\
\hline Larg. do clípeo nas fóveas tentoriais & 0,42 & 0,41 & 0,40 & 0,44 & 0,41 \\
\hline Distância clipeocelar (ocelo médio) & 1,10 & 1,13 & 1,12 & 1,19 & 1,06 \\
\hline Comprimento da área malar & 0,12 & 0,15 & 0,14 & 0,16 & 0,12 \\
\hline Comprimento do escapo & 0,72 & 0,67 & 0,76 & 0,84 & 0,70 \\
\hline Diâm. escapo (base/meio/ápice) & $0,08 / 0,07$ & $0,07 / 0,07 / 0,08$ & $0,08 / 0,07 / 0,08$ & $0,10 / 0,08 / 0,12$ & $0,08 / 0,06 / 0,08$ \\
\hline Diâmetro $2^{\circ}$ fl. (max/min) & 0,09 & 0,10 & $0,10 / 0,08$ & $0,11 / 0,08$ & $0,09 / 0,08$ \\
\hline Comprimento do pedicelo & $? ?$ & 0,13 & 0,18 & 0,22 & 0,17 \\
\hline Comprimento do $1^{\circ} \mathrm{fl}$. & 0,10 & 0,11 & 0,13 & 0,15 & 0,12 \\
\hline Comprimento da mandíbula & 0,60 & 0,59 & 0,58 & 0,62 & 0,58 \\
\hline Comprimento da asa anterior & & & & & \\
\hline $\begin{array}{l}\text { (do ápice do esclerito } \mathrm{C} / \text { + tégula) } \\
\text { Largura da asa anterior }\end{array}$ & $\begin{array}{c}* 2,6 / / 3,03 \\
?\end{array}$ & $\begin{array}{c}3,15 / 3,45 \\
1,20\end{array}$ & $\begin{array}{l}*, / 0 / 3,00^{* *} \\
* 1,08 * *\end{array}$ & $\begin{array}{c}2,40 / 2,70 \\
1,30\end{array}$ & $\begin{array}{c}2,52 / 2,85 \\
1,04\end{array}$ \\
\hline Largura do mesoscuto & $?$ & 1,05 & 0,93 & 0,88 & 0,84 \\
\hline Comprimento do mesoscuto & $?$ & 0,80 & 0.69 & 0,72 & 0,64 \\
\hline Largura do escutelo & $?$ & 0,59 & 0,50 & 0,53 & 0,46 \\
\hline Comprimento do escutelo & $?$ & 0,27 & 0,22 & 0,23 & 0,22 \\
\hline Comprimento da tíbia III & $?$ & 1,37 & 1,44 & 1,52 & 1,32 \\
\hline Largura máxima da tíbia III & $?$ & 0,38 & 0,38 & 0,36 & 0,33 \\
\hline Comprimento do basitarso III & $?$ & 0,53 & 0,48 & 0,62 & 0,48 \\
\hline Largura do basitarso III & $?$ & 0,26 & 0,24 & 0,24 & 0,22 \\
\hline Largura do TIII & 1,00 & $?$ & $* 1,06 * *$ & 1,36 & 1,02 \\
\hline Compr. cerdas do escapo (base/meio/ápice) & glabro & 0,05 (base) & glabro & $0,08 / 0,06 / 0,05$ & $0,11 / 0,07 / 0,06$ \\
\hline Compr. cerdas do clípeo & glabro & 0,11 & 0,05 & 0,11 & 0,12 \\
\hline Compr. cerdas área parocular inferior & glabro & 0,03 & glabro & 0,04 & 0,18 \\
\hline Compr. cerdas da área supra-clipeal & glabro & 0,09 & glabra & 0,06 & 0,10 \\
\hline Compr. cerdas entre os alvéolos ant. & glabro & 0,08 & 0,06 & 0,17 & 0,09 \\
\hline Compr. cerdas pedicelo / $1^{\circ} \mathrm{fl}$. & $0,03 /$ glabro & $0,05 /$ glabro & 0,03 / glabro & $0,08 / 0,08$ & $0,08 / 0,14$ \\
\hline Compr. cerdas do vértice & 0,06 & 0,17 & 0,11 & 0,18 (ocelo) & 0,12 \\
\hline Compr. cerdas do disco do mesoscuto & 0,04 & 0,11 & 0,07 & 0,16 & 0,11 \\
\hline Compr. cerdas da porção anterior do mesoscuto & 0,05 & 0,15 & glabro & 0,16 & 0,13 \\
\hline Comprimento das cerdas do escutelo & $?$ & 0,27 & 0,21 & 0,36 & 0,21 \\
\hline
\end{tabular}


Tabela II. Medidas (mm) dos holótipos, operárias, de Dolichotrigona tavaresi sp. nov., D. browni sp. nov., D. moratoi sp. nov., D. chachapoya sp. nov., e macho de D. tavaresi sp. nov. (* medidas aproximadas).

\begin{tabular}{|c|c|c|c|c|c|}
\hline Medidas (mm) & D. tavaresi & D. browni & D. moratoi & D. chachapoya & $\begin{array}{l}\text { D. tavaresi } \\
\text { macho }\end{array}$ \\
\hline Comprimento total aproximado & 3,03 & 3,21 & 3,24 & 2,91 & 3,87 \\
\hline Largura máxima da cabeça & 1,42 & 1,48 & 1,50 & 1,33 & 1,40 \\
\hline Comprimento da cabeça & 1,24 & 1,28 & 1,28 & 1,18 & 1,24 \\
\hline Comprimento do olho & 0,92 & 0,90 & 0,94 & 0,83 & 1,00 \\
\hline Largura do olho & 0,40 & 0,40 & 0,42 & 0,37 & 0,46 \\
\hline Distância interorbital superior & 0,87 & 0,94 & 0,93 & 0,82 & 0,80 \\
\hline Distância interorbital máxima & 0,98 & 1,05 & 1,04 & 0,94 & 0,85 \\
\hline Distância interorbital inferior & 0,84 & 0,90 & 0,88 & 0,82 & 0,63 \\
\hline Diâmetro do ocelo médio & 0,11 & 0,11 & 0,11 & 0,09 & 0,16 \\
\hline Distância entre os ocelos laterais & 0,26 & 0,27 & 0,28 & 0,24 & 0,26 \\
\hline Distância ocelorbital (ocelo lateral) & 0,22 & 0,26 & 0,24 & 0,23 & 0,16 \\
\hline Distância interalveolar & 0,09 & 0,10 & 0,10 & 0,09 & 0,12 \\
\hline Distância alveolorbital & 0,26 & 0,30 & 0,32 & 0,27 & 0,17 \\
\hline Distância alvéolo-ocelo lateral & 0,67 & 0,66 & 0,68 & 0,61 & 0,63 \\
\hline Diâmetro do alvéolo & 0,13 & 0,12 & 0,13 & 0,14 & 0,14 \\
\hline Comprimento do clípeo & 0,32 & 0,33 & 0,31 & 0,26 & 0,32 \\
\hline Largura máxima do clípeo & 0,72 & 0,72 & 0,66 & 0,60 & 0,56 \\
\hline Larg. do clípeo nas fóveas tentoriais & 0,38 & 0,42 & 0,42 & 0,40 & 0,36 \\
\hline Distância clipeocelar (ocelo médio) & 1,10 & 1,14 & 1,14 & 1,04 & 1,08 \\
\hline Comprimento da área malar & 0,12 & 0,13 & 0,12 & 0,14 & 0,02 \\
\hline Comprimento do escapo & 0,75 & 0,78 & 0,74 & 0,64 & 0,50 \\
\hline Diâm. escapo (base/meio/ápice) & $0,09 / 0,06 / 0,08$ & $0,08 / 0,06 / 0,09$ & $0,10 / 0,07 / 0,10$ & $0,07 / 0,05 / 0,08$ & 0,11 \\
\hline Diâmetro $2^{\circ}$ fl. (max/min) & $0,09 / 0,07$ & $0,08 / 0,07$ & $0,09 / 0,07$ & $0,08 / 0,07$ & 0,10 \\
\hline Comprimento do pedicelo & 0,17 & 0,19 & 0,20 & 0,15 & 0,13 \\
\hline Comprimento do $1^{\circ} \mathrm{fl}$. & 0,11 & 0,11 & 0,11 & 0,07 & 0,04 \\
\hline Comprimento da mandíbula & 0,62 & 0,64 & 0,64 & 0,56 & 0,45 \\
\hline $\begin{array}{l}\text { Comprimento da asa anterior } \\
\text { (do ápice do esclerito } \mathrm{C} /+ \text { tégula) }\end{array}$ & $2,75 / 3,06$ & $2,88 / 3,27$ & $2,85 / 3,18$ & $2,67 / 3,00$ & $2,88^{*}$ \\
\hline Largura da asa anterior & ? & 1,14 & 1,20 & 1,13 & $?$ \\
\hline Largura do mesoscuto & 0,92 & 1,00 & 0,96 & 0,90 & 1,00 \\
\hline Comprimento do mesoscuto & 0,70 & 0,70 & 0,68 & 0,66 & 0,92 \\
\hline Largura do escutelo & 0,52 & 0,52 & 0,52 & 0,52 & 0,56 \\
\hline Comprimento do escutelo & 0,22 & 0,24 & 0,22 & 0,24 & 0,25 \\
\hline Comprimento da tíbia III & 1,42 & 1,42 & 1,44 & 1,24 & 1,28 \\
\hline Largura máxima da tíbia III & 0,36 & 0,36 & 0,37 & 0,34 & 0,37 \\
\hline Comprimento do basitarso III & 0,52 & 0,60 & 0,58 & 0,52 & 0,42 \\
\hline Largura do basitarso III & 0,22 & 0,24 & 0,24 & 0,21 & 0,21 \\
\hline Largura do TIII & 1,06 & 1,17 & 1,20 & 1,08 & $?$ \\
\hline Compr. cerdas do escapo (base/meio/ápice) & $0,16 / 0,10 / \mathrm{glb}$ & $0,15 / 0,07 / 0,03$ & $0,26 / 0,17 / 0,13$ & $0,10 / 0,08 / 0,04$ & 0,04 \\
\hline Compr. cerdas do clípeo & 0,10 & 0,10 & 0,16 & 0,16 & 0,06 \\
\hline Compr. cerdas área parocular inferior & 0,12 & 0,08 & 0,18 & 0,15 & 0,06 \\
\hline Compr. cerdas da área supra-clipeal & 0,15 & 0,15 & 0,11 & 0,09 & $?$ \\
\hline Compr. cerdas entre os alvéolos ant. & 0,12 & 0,11 & 0,12 & 0,11 & $?$ \\
\hline Compr. cerdas pedicelo / $1^{\circ} \mathrm{fl}$ & $0,07 / 0,02$ & $0,05 / 0,06$ & $0,12 / 0,14$ & $0,06 / 0,04$ & $0,03 / 0,02$ \\
\hline Compr. cerdas do vértice & 0,11 & 0,13 & 0,14 & 0,12 & 0,18 \\
\hline Compr. cerdas do disco do mesoscuto & 0,11 & 0,12 & 0,12 & 0,09 & 0,09 \\
\hline Compr. cerdas da porção anterior do mesoscuto & 0,10 & 0,12 & 0,17 & 0,12 & 0,10 \\
\hline Comprimento das cerdas do escutelo & 0,22 & 0,22 & 0,23 & 0,20 & 0,24 \\
\hline
\end{tabular}


Distribuição geográfica e hábitat. Conhecida apenas da localidade do tipo (veja "Discussão"; Fig. 44).

\section{Nidificação. Desconhecida.}

Discussão. Pela presença de um só dentículo na mandíbula e pelas cerdas muito curtas no escapo, assemelha-se mais a $D$. longitarsis, D. clavicornis sp. nov. e D. schulthessi, todavia, distingue-se pelo escapo mais curto, ca. 0,94x a distância alveolocelar, e pela veia $\mathrm{M}$ mais longa que Rs+M. Em $D$. longitarsis o escapo é nitidamente mais longo que a distância alveolocelar, e em $D$. schulthessi, se iguala a essa distância. Em D. clavicornis sp. nov., o escapo além de mais longo, é expandido no terço apical. Nestas espécies a veia M, é um pouco mais arqueada e mais curta que Rs+M (como na Fig. 37). Também, em $D$. martinezi o basitarso III é um pouco mais largo $(0,49 \mathrm{x}$ de seu comprimento) que em $D$. longitarsis $(0,40-$ $0,43 \mathrm{x}$ ) e $D$. schulthessi (ca. $0,47 \mathrm{x}$ ); desta última distingue-se ainda pelo comprimento das cerdas do vértice da cabeça; nesta, as maiores cerdas se igualam ao diâmetro do escapo, enquanto que em $D$. martinezi são duas vezes mais longas. Apesar dos caracteres relacionados acima, como distintivos de $D$. martinezi, é com algum receio que conservamos seu status de espécie, visto que só se conhece um exemplar. Suspeitamos que possa ser apenas uma variação geográfica de $D$. longitarsis. Ademais, há dúvidas também quanto a procedência (Lima) do espécime-tipo. Brèthes (1920: 53-54) relaciona, além de T. martinezi, algumas outras espécies de Meliponini etiquetadas como procedentes de Lima: Trigona bipunctata limae Brèthes, 1920 [ = Scaptotrigona limae], Trigona molesta Puls [prov. Plebeia molesta (Puls, 1869)], Trigona longipes Smith [prov. Frieseomelitta varia (Lepeletier, 1836)] e Trigona fulvohirta Friese [prov. Geotrigona fulvohirta (Friese, 1900)]. Todavia, todas essas espécies só são conhecidas no lado oriental dos Andes, e, além disso, não temos conhecimento de qualquer outro registro de Meliponini na região de Lima. Pela costa do Pacífico, o registro mais ao sul que se conhece é de $P$. peckolti (Friese, 1900), em Trujillo, Peru (Camargo \& Pedro 2003: 328), ca. $500 \mathrm{~km}$ ao norte de Lima. De acordo com o Dr. Gerardo Lamas, da Universidade Nacional Mayor de San Marcos, Lima (in litt.), o coletor de D. martinezi, Ezequiel A. Martinez, fez pelo menos uma viagem à região de Chanchamayo em 1918, e é possível que os Meliponini enviados para Brèthes em "11.1919", fossem procedentes dessa região e não de "Lima", como consta na etiqueta de D. martinezi. Todavia, até que se colete outros exemplares correspondentes a $D$. martinezi, seu status não pode ser devidamente esclarecido.

Dolichotrigona schulthessi (Friese, 1900) comb. nov.

(Figs. 6, 16, 30, 44)

Trigona schulthessi Friese, 1900: 386; Friese, 1902: 383; Cockerell, 1911: 286; Schwarz, 1934: 3, 22; Bernal \& Ervik, 1996: 691.

Trigona (Hypotrigona) schulthessi; Schwarz, 1938: pl. 60B; Michener, 1954: 172.

Trigonisca schulthessi; Wille, 1965: 139; Michener, 1990: 132; Michener, 2000: 805; ?Roubik, 1992: 499, 501, 503, 513 (error, a fig. 31.10 não corresponde a Dolichotrigona), 518, 523; Roubik, 2000: 146; Griswold et al., 1995: 690; ?Smith-Pardo, 2003: 338; ?Nates-Parra, 2001: 241, 248 (partim).

Dolichotrigona longitarsis; Bego et al., 1991: 125 (cit., error, non Ducke, 1916).

Dolichotrigona longitarsus [sic]; Sakagami et al., 1993: 243 (error, non Ducke, 1916, refere-se às abelhas do Panamá).

Trigonisca (Dolichotrigona) schulthessi; Ayala, 1999: 8, 14, 114, 116; Michener \& Roubik, 1993: 256; Roubik, 1993: 549.

Trigonisca schultesii [sic]; Pereboom \& Biesmeijer, 2003: 43, 44.

Diagnose. Operária. Largura da cabeça entre 1,30-1,51, comprimento da asa anterior, ca. 3,0; mandíbula com 1 dentículo (Fig. 6); escapo normal (Fig. 16), tão longo quanto a distância alveolocelar; $1^{\circ} \mathrm{fl}$. longo, comprimento aproximadamente igual à sua largura (Fig. 16); cerdas do escapo mais curtas que o diâmetro deste (Fig. 16); pedicelo e $1^{\circ}$ fl. com cerdas curtas, menores que metade do diâmetro destes ou ausentes (Fig. 16); área parocular inferior com cerdas eretas curtas, ca. metade do diâmetro do $2^{\circ}$ fl. (como na Fig. 24); cerdas do bordo posterior do escutelo aproximadamente tão longas quanto o comprimento deste; membrana das asas hialina; veia $\mathrm{M}$ levemente arqueada (como na Fig. 37).

Material-tipo. Friese (1900) refere-se a três operárias de Guatemala, coletadas por Stoll, provavelmente depositadas no museu de Berlim (Zoologisches Museum der Humboldt Universität, Berlim), segundo Ayala (1999: 114). Roubik (1992: 518) refere-se a "homótipos" da Costa Rica no U.S. National Museum of Natural History, Smithsonian Institution. Não foram examinados.

Material examinado. HONDURAS. Olancho: Cecilia [prov. Cerro Cecilia, 14 $\left.49^{\prime} \mathrm{N}, 86^{\circ} 36^{\prime} \mathrm{W}\right]$, sem data, anônimo (1 op., DZUP). NICARÁGUA. Granada: Volcan Mombacho, San Joaquim, 15.IV.1998, J. M. Maes (1 macho, ISNB); ibidem, idem, 30.IV.1998, Malaise trap (1 op., ISNB). COSTA RICA. Puntarenas: El Cacique, cerca rio Changuina, 22.II.1961, Wille (1 op., DZUP); Gromaco, 34 Km SE of Potrero Grande, on Rio Coto Brus, 21.VII.1963, 1000 ft., C. D. Michener, W. Kerfoot (1 op., DZUP; 2 ops., RPSP). Cartago: Turrialba, 5.VII.1963, 1950 ft., C. D. Michener et al. (1 op., RPSP). Prov. ?: Hamburg Farm, 25.X.1937, F. Nevermann, nest no. 30, acc. 35816, "Trigona schulthessi Friese Det. Schwarz" [1 op.] e "Trigona (Hypotrigona) schulthessi Fr. Det. H. F. Schwarz" [1 alf. com 4 ops.] (5 ops., RPSP). COLÔMBIA. Boyaca: Muzo, 1260 ms, II.1957, J. Foerster (3 ops., DZUP).

Distribuição geográfica e hábitat. Norte da Colômbia até México (sudoeste de Chiapas, Ayala 1999) (Fig. 44). Há registro de ocorrência no Panamá (Prov. Chiriqui, Progreso) em Schwarz (1934) e Michener (1954).

Nidificação. Desconhecida. Roubik (1992) menciona "Trigonisca aff. schulthessi", do Panamá, nidificando em oco de árvore viva [citada erroneamente como Trigona (Trigonisca) buyssoni Friese, 1902 em Roubik, 1983, onde apresenta mais detalhes do ninho], porém há dúvidas se a espécie mencionada é realmente uma Dolichotrigona.

Discussão. A espécie foi interpretada com base na descrição original de Friese (1900), notas de Schwarz (1934), e em exemplares provenientes de Costa Rica, identificados por Schwarz. Pode ser reconhecida pelas cerdas curtas no escapo, 


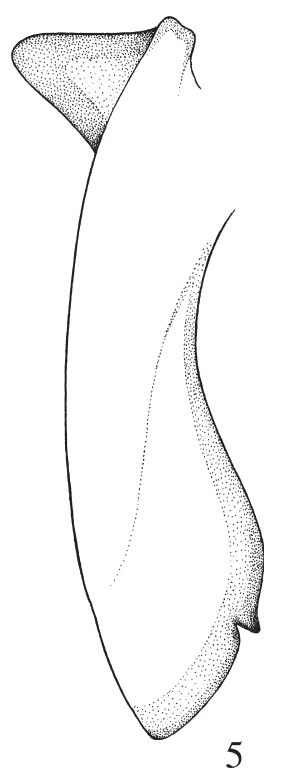

5

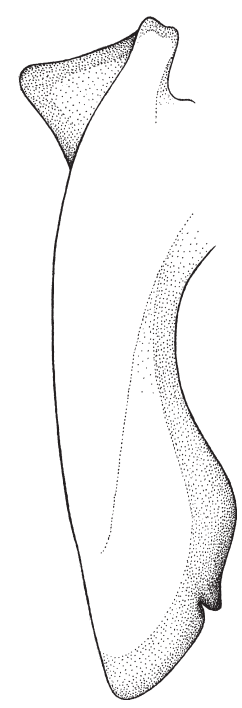

6

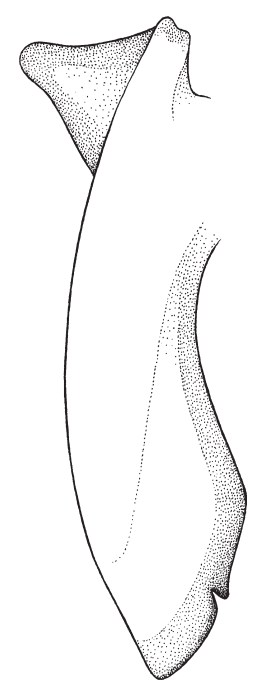

7
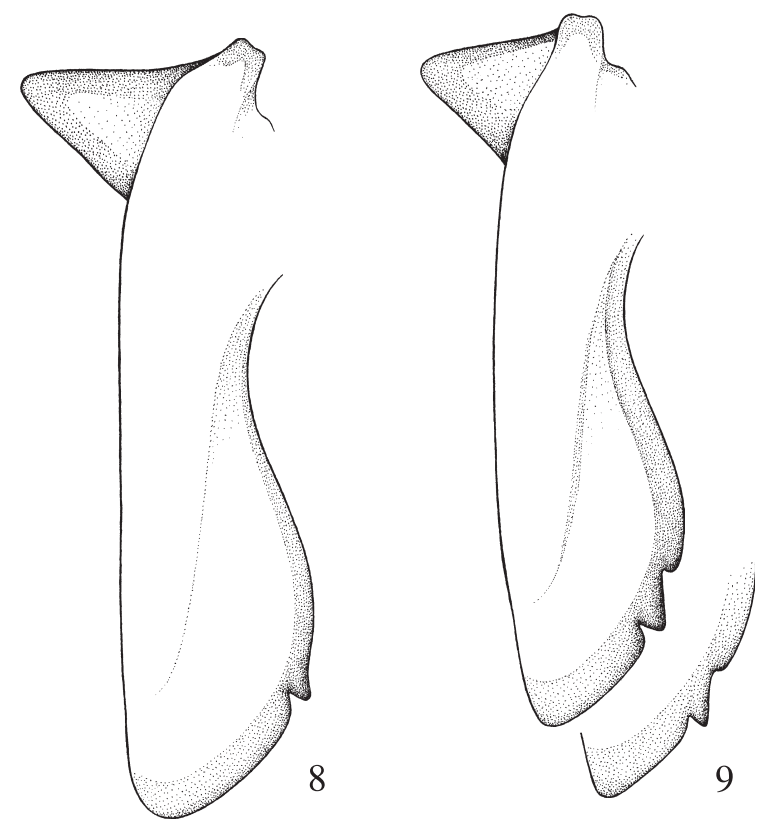
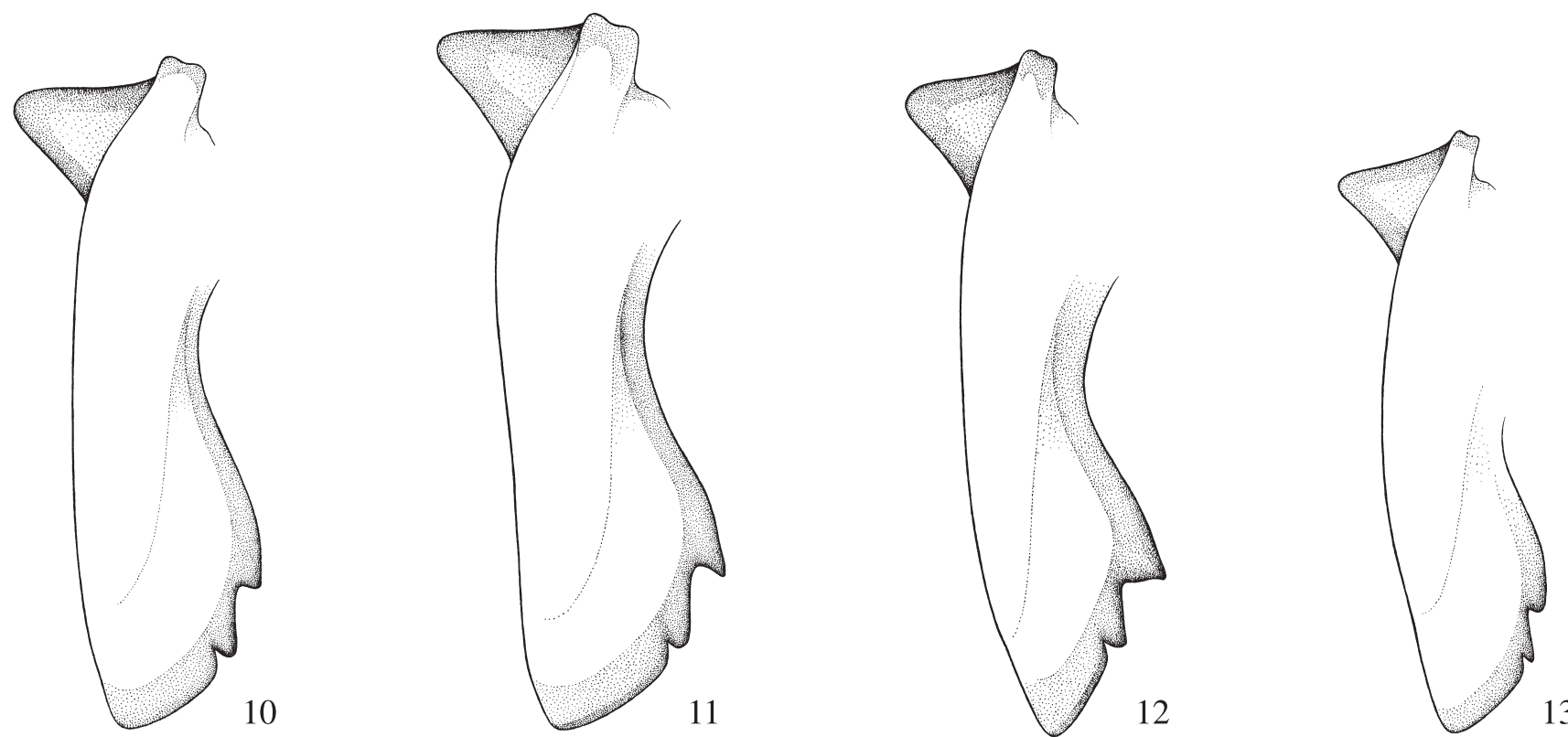

Figs. 5-13. Dolichotrigona, mandíbulas. 5, D. longitarsis; 6, D. schulthessi; 7, D. mendersoni sp. nov.; 8, D. clavicornis sp. nov.; 9 , D. rondoni sp. nov.; 10, D. tavaresi sp. nov.; 11, D. browni sp. nov.; 12, D. moratoi sp. nov.; 13, D. chachapoya sp. nov. Escala $=0,5 \mathrm{~mm}$.

pedicelo e $1^{\circ} \mathrm{fl}$., ausência de cerdas eretas na área parocular inferior, presença de apenas um dentículo na mandíbula, caracteres que compartilha com $D$. longitarsis, $D$. clavicornis sp. nov. e $D$. martinezi. Das duas primeiras, pode ser distinguida pelas asas hialinas, escapo proporcionalmente mais curto, igual a distância alveolocelar, e pelas cerdas do bordo posterior do escutelo, mais curtas, aproximadamente tão longas quanto o comprimento deste. De D. martinezi, separa-se pelo escapo um pouco mais longo e pela veia $\mathrm{M}$ levemente arqueada e mais curta que Rs + M. O exemplar de Cecília, Honduras é bastante pequeno (largura da cabeça 1,30) e descolorido, as pernas posteriores são bem amareladas quando comparado com os exemplares de Costa Rica, maiores (largura da cabeça 1,48-1,51) e bem enegrecidos. É provável que $D$. schulthessi, como vem sendo interpretada, inclua mais que uma espécie.

\section{Dolichotrigona mendersoni sp. nov.}

(Figs. 7, 17, 25, 31, 44; Tabela I)

Diagnose. Operária. Largura da cabeça entre 1,37-1,40, 
comprimento da asa anterior, ca. 2,70; mandíbula com 1 dentículo (Fig. 7); escapo normal (Fig. 17), ca. 1,1x a distância alveolocelar; $1^{\circ} \mathrm{fl}$. longo, comprimento aproximadamente igual à sua largura (Fig. 17); escapo e $1^{\circ}$ fl. glabros (Fig. 17); pedicelo com algumas cerdas muito curtas, menores que metade do diâmetro deste (Fig. 17); área parocular inferior glabra (Fig. 25); labro com forte depressão mediana longitunal (Fig. 31); cerdas do bordo posterior do escutelo aproximadamente tão longas quanto o comprimento deste; membrana das asas hialina.

Holótipo, operária (Figs. 7, 17, 25, 31; Tabela I).

Dimensões. Comprimento total aproximado, 2,88; da asa anterior, 2,70* (incluindo a tégula, 3,00*); largura máxima da cabeça, 1,40; do TIII, $1,10^{*}$ (* medidas tomadas no parátipo de Extrema-RO, n 11363 , com largura máxima da cabeça igual a 1,38).

Cor do integumento. Preto, apenas os tarsômeros de todos os pares de pernas e basitarso III, mandíbula e labro, castanhos; base do escapo e ápice do último fl., castanho-amarelados; margem das tégulas e margem dos TIII-TVI, translúcidos. Membrana das asas hialina; microtríquias castanhas; veias méleas.

Pilosidade. Cerdas eretas ausentes no escapo, fronte, áreas paroculares e lados dos mesepisternos, apenas com microcerdas decumbentes, quase imperceptíveis, aparentemente simples, dependendo da iluminação. No clípeo, 2-3 cerdas eretas simples, esparsas, um pouco mais curtas que o diâmetro do escapo; na área entre os alvéolos antenais, algumas cerdas eretas, simples e robustas, tão longas quanto o diâmetro do escapo, ou um pouco mais curtas (Fig. 25). No vértice, algumas cerdas eretas restritas à porção mediana (Fig. 25), tão longas quanto o diâmetro do escapo $(0,09)$; uma cerda próxima a margem interna do ocelo lateral esquerdo, um pouco mais longa $(0,11$; falta a do lado direito). Mesoscuto sem cerdas eretas no bordo anterior, apenas algumas cerdas eretas acompanhando as margens laterais e umas poucas no disco, quase tão longas quanto o diâmetro do escapo; escutelo e axilas com cerdas eretas apenas no bordo posterior, as maiores quase tão longas quanto o comprimento do escutelo.

\section{Integumento. Como descrito para o gênero.}

Forma e proporções (medidas na Tabela I). Cabeça 1,09x mais larga que longa e 1,25x mais larga que a distância clipeocelar. Olhos 2,35x mais longos que largos, levemente convergentes embaixo. Área malar $1,56 \mathrm{x}$ mais longa que a largura máxima do $2^{\circ} \mathrm{fl}$. Clípeo $0,49 \mathrm{x}$ mais curto que sua largura máxima e 0,29x a distância clipeocelar. Mandíbulas tão longas quanto 0,52x a distância clipeocelar; com um dentículo agudo, aproximadamente na metade do bordo distal, projetando-se além da margem (Fig. 7). Labro biconvexo, com forte depressão longitudinal mediana, entre as duas convexidades (Fig. 31).
Escapo 1,10x a distância alveolocelar, levemente alargado em direção ao ápice (Fig. 17). O $1^{\circ}$ fl. tão longo quanto largo (Fig. 17). Distância interocelar $1,24 x$ maior que a ocelorbital e $2,17 x$ o diâmetro do ocelo médio. Escutelo 0,44x mais curto que largo. Tíbia III 1,03x a largura da cabeça, e 3,79x mais longa que larga. Basitarso III 2,00x mais longo que largo; canto póstero-distal formando ângulo agudo em relação a margem posterior. Asa anterior ca. 2,50x mais longa que larga, e 1,93x mais longa que a largura da cabeça.

Material-tipo. Holótipo, operária, de "Rio Ipixuna, Purus-AM, Brasil 20,23-I-1986, 860835”, “SB-20, 6320'W - 60’S, Camargo Mazucato", depositado na RPSP. Parátipos, 3 operárias, das seguintes localidades: BRASIL. Rondônia: Extrema, Linha 4, 0944'56.5"S, 66²6'58.5"W, 26.VI.1997, Brown, Boina, Vieira (2 ops., RO-11325, RO-11363, RPSP); Acre: Reserva Estrat. [sic = Extrat.] Boa Esperança, Porto Dias, 11.XII.1994, F. J. A. Peralta (1 op., INPA).

Distribuição geográfica e hábitat. Conhecida apenas do Brasil, região do Rio Ipixuna, Purus, até extremo oeste de Rondônia e leste do Acre (Fig. 44).

Nidificação. Desconhecida.

Etimologia. O nome da espécie é uma homenagem a Menderson Mazucato, que durante mais de 25 anos, dedicouse aos serviços de preparação e montagem de material, além da inestimável contribuição para o aumento do acervo da coleção de abelhas da RPSP, como exímio coletor que é, e pelo companheirismo nas expedições de coleta.

Discussão. Dolichotrigona mendersoni sp. nov. compartilha com $D$. schulthessi, D. martinezi, D. longitarsis e D. clavicornis sp. nov. a condição unidentada da mandíbula, porém pode ser facilmente reconhecida pela ausência de cerdas eretas, principalmente no escapo e face, além do labro, fortemente marcado por uma depressão longitudinal.

\section{Dolichotrigona clavicornis sp. nov.} (Figs. 8, 18, 32, 44; Tabela I)

Diagnose. Operária. Largura da cabeça entre 1,45-1,54, comprimento da asa anterior entre 3,15-3,00; mandíbula com 1 dentículo (Fig. 8); escapo estreitado medianamente e bojudo no terço apical (Fig. 18), ca. 1,2x a distância alveolocelar; $1^{\circ} \mathrm{fl}$. longo, comprimento aproximadamente igual à sua largura (Fig. 18); cerdas do escapo mais curtas que o diâmetro deste (Fig. 18); pedicelo e $1^{\circ} \mathrm{fl}$. com cerdas curtas, menores o diâmetro destes ou ausentes (Fig. 18); área parocular inferior com cerdas eretas curtas, ca. metade do diâmetro do $2^{\circ}$ fl. (como na Fig. 24); cerdas do bordo posterior do escutelo ca. 1,6x o comprimento deste; membrana das asas hialina.

Holótipo, operária (Figs. 8, 18, 32; Tabela I).

Dimensões. Comprimento total aproximado, 2,67; da asa anterior, 2,40 (incluindo a tégula, 2,70); largura máxima da cabeça, 1,50; do TIII, 1,36. 


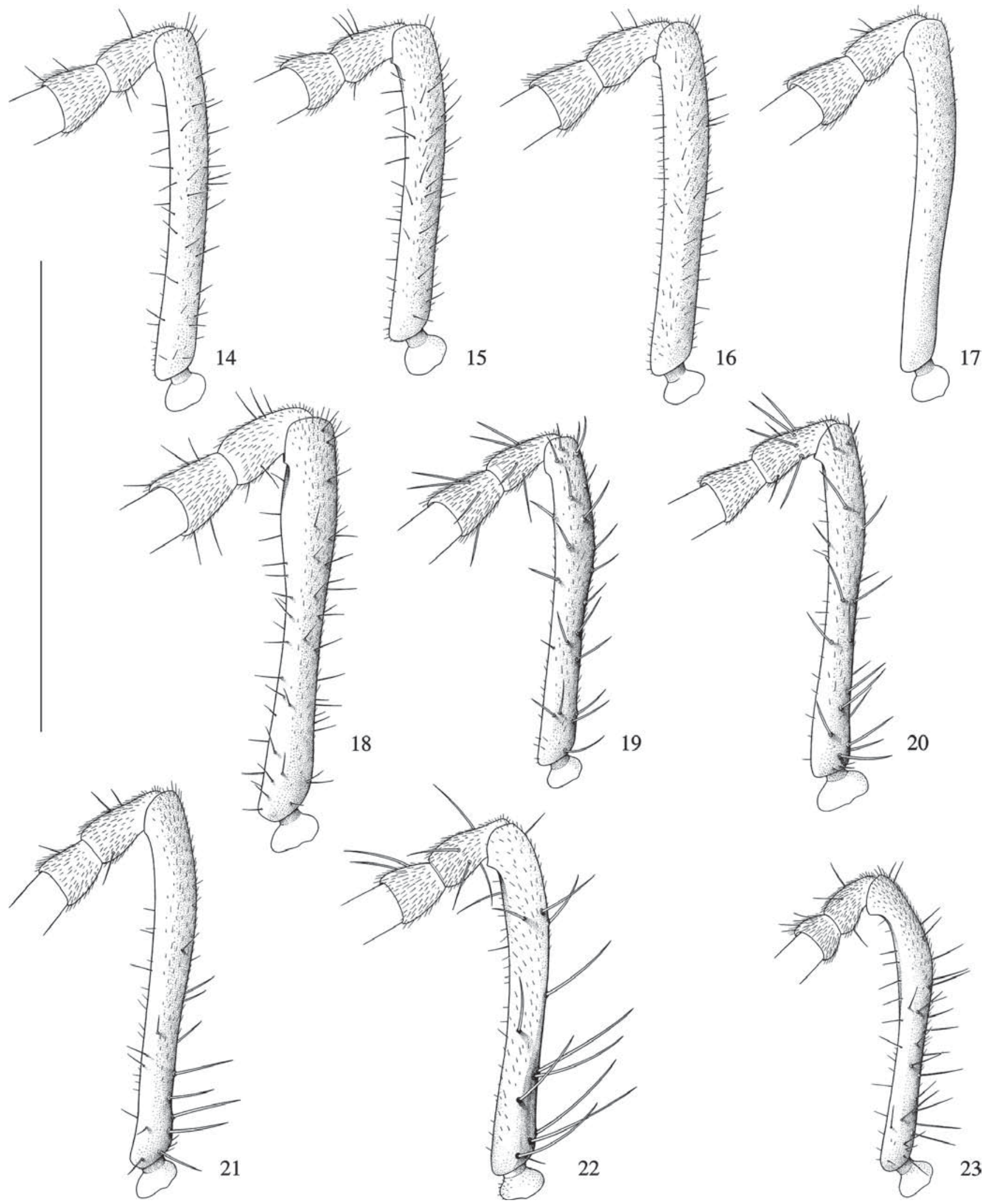

Figs. 14-23. Dolichotrigona, antenas (escapo, pedicelo e $1^{\circ}$ artículo do flagelo). $14, D$. longitarsis; $15, D$. martinezi; $16, D$. schulthessi; $17, D$. mendersoni sp. nov.; 18, D. clavicornis sp. nov.; 19, D. rondoni sp. nov.; 20, D. tavaresi sp. nov.; 21, D. browni sp. nov.; 22 , D. moratoi sp. nov.; 23, D. chachapoya sp. nov. Escala $=1,0 \mathrm{~mm}$. 
Cor do integumento. Preto, apenas as mandíbulas, face inferior dos escapos e ápice do último fl., ferrugíneoamarelados; labro, clípeo (mancha difusa nos $2 / 3$ apicais), área supra-clipeal, paroculares inferiores, face externa dos escapos, basitarso da perna III e tarsômeros de todos os pares de pernas, ferrugíneo-escuros, apenas um pouco mais claros que o restante do integumento. Olhos de cor âmbar-avermelhada. Margem das tégulas translúcida. Membrana das asas levemente ferrugínea; microtríquias castanhas; veias méleas.

Pilosidade. Cerdas do escapo curtas, eretas, esparsas, simples, menores que o diâmetro deste e distribuídas da base até o ápice; pedicelo e $1^{\circ} \mathrm{fl}$. com algumas cerdas eretas, um pouco mais curtas que o diâmetro dos respectivos artículos (Fig. 18). Área parocular inferior, um pouco abaixo dos alvéolos antenais, com algumas cerdas eretas, esparsas, simples, mais curtas que o diâmetro do $2^{\circ} \mathrm{fl}$., pouco distintas da micropilosidade decumbente; na área entre os alvéolos antenais, duas cerdas simples, eretas, longas, ca. 1,75x o diâmetro do escapo, mais robustas que aquelas do escapo; mais algumas cerdas, um pouco mais curtas, na área supraclipeal. As cerdas eretas do clípeo, um pouco mais longas, ca. 1,4x o diâmetro do escapo; na fronte, um pouco mais curtas; no vértice, as mais longas, ca. 1,5x o diâmetro do escapo; próximo à margem interna de cada um dos ocelos laterais, uma cerda mais longa (ca. $2 \mathrm{x}$ o diâmetro do escapo), com o ápice voltado em direção ao olho composto. No escutelo, as cerdas do bordo posterior, muito longas ca. 1,6x o comprimento deste; na área discal, algumas cerdas eretas um pouco mais curtas.

Integumento. Como descrito para o gênero.

Forma e proporções (medidas na Tabela I). Cabeça 1,12x mais larga que longa e 1,26x mais larga que a distância clipeocelar (Fig. 32). Olhos 2,20x mais longos que largos, levemente convergentes embaixo. Área malar 1,45x mais longa que o diâmetro máximo do $2^{\circ} \mathrm{fl}$. Clípeo $0,49 \mathrm{x}$ mais curto que sua largura máxima e $0,29 \mathrm{x}$ a distância clipeocelar. Mandíbulas $0,52 \mathrm{x}$ a distância clipeocelar; com um dentículo agudo (Fig. 8). Labro uniformemente convexo, praticamente sem depressão mediana (Fig. 32). Escapo 1,18x a distância alveolocelar, e bojudo no terço apical (Figs. 18, 32). O $1^{\circ}$ fl. tão longo quanto largo (Fig. 18). Distância interocelar $1,15 \mathrm{x}$ maior que a ocelorbital e 2,50x o diâmetro do ocelo médio. Escutelo 0,43x mais curto que largo. Tíbia III 1,01x a largura da cabeça e 4,22x mais longa que larga. Basitarso III 2,58x mais longo que largo; canto póstero-distal em ângulo agudo. Asa anterior ca. 1,85x mais longa que larga, e 1,6x mais longa que a largura da cabeça. Veia M levemente arqueada (como na Fig. 37).

Material-tipo. Holótipo, operária, de "BRASIL Acre, Parque Nacional Serra do Divisor, T. de caça Piroca, Sítio 3, 07²8'38"S, 7341'54"W, 12-13.XI.1996, E. F. Morato, 970990"; parátipos, 11 operárias, sendo 8 com etiquetas de procedência iguais às do holótipo (970964, 970966, 970971, 970973, 970981, 97082, 970983, 970991), e 3 procedentes de "BRASIL, Acre, Parque Nacional Serra do Divisor, Trilha do Anil, Sítio 6, 07²6’27"S, 73³9’28"W, 8-9.XI.1996, E. F. Morato" (971579, 971580, 971581); todos depositados na RPSP.
Distribuição geográfica e hábitat. Conhecida apenas do estado do Acre, Brasil.

\section{Nidificação. Desconhecida.}

Etimologia. Do latim, clava + cornu $=$ chifre, antena dos insetos, referindo-se a forma clavada da antena.

Discussão. Dolichotrigona clavicornis sp. nov. pode ser facilmente reconhecida dentre as demais espécies de Dolichotrigona, pelo escapo bojudo no terço apical e pelas cerdas muito longas no bordo posterior do escutelo, ca. 1,6x o comprimento deste. É muito semelhante a $D$. longitarsis com a qual compartilha, além das cerdas curtas na face e escapo e presença de um dente na mandíbula, as asas levemente ferrugíneas, mas separa-se pelos caracteres citados acima.

\section{Dolichotrigona rondoni sp. nov.}

(Figs. 9, 19, 33, 44; Tabela I)

Diagnose. Operária. Largura da cabeça entre 1,28-1,42, comprimento da asa anterior, ca. 2,46-2,70; mandíbula com 2 dentículos, o dente do canto interno muito curto ou inconspícuo, indicado apenas por uma leve reentrância (Fig. 9); escapo normal (Fig. 19), 1,1x a distância alveolocelar; $1^{\circ} \mathrm{fl}$. longo, comprimento aproximadamente igual à sua largura (Fig. 19); cerdas eretas do escapo, robustas, ca. 1,0-2,0x o diâmetro deste, distribuídas desde a base até o ápice, na base, um pouco mais longas (Fig. 19); pedicelo e $1^{\circ} \mathrm{fl}$. com cerdas eretas, robustas, tão longas ou um pouco mais que o diâmetro destes (Fig. 19); área parocular inferior, próxima a porção inferior dos alvéolos antenais, com pelo menos uma cerda muito grossa e longa, ca. 2,0x o diâmetro do $2^{\circ} \mathrm{fl}$.; cerdas do bordo posterior do escutelo $0,9-1,1 \mathrm{x}$ o comprimento deste; membrana das asas hialina.

Holótipo, operária (Fig. 19, holótipo, Figs. 9, 33, parátipos; Tabela II).

Dimensões. Comprimento total aproximado, 2,76; da asa anterior, 2,52 (incluindo a tégula, 2,85); largura máxima da cabeça, 1,35; do TIII, 1,02.

Cor do integumento. Preto, apenas as mandíbulas, tíbia, basitarso e tarsômeros das pernas III, castanhos; ápice da mandíbula, base do escapo e ápice do último fl., castanhoamarelados; margem das tégulas e margem dos TIII-TVI, translúcidas. Membrana das asas hialina; microtríquias castanhas; veias méleas.

Pilosidade. Cerdas do escapo longas, eretas, esparsas, distribuídas da base até o ápice, exceto na face interna; na base, um pouco mais longas que o diâmetro deste e um pouco mais curtas para o ápice (Fig. 19); pedicelo com 5 cerdas, eretas, as maiores aproximadamente tão longas quanto o diâmetro deste (Fig. 19); $1^{\circ}$ fl. com 4 cerdas eretas, um pouco mais longas 

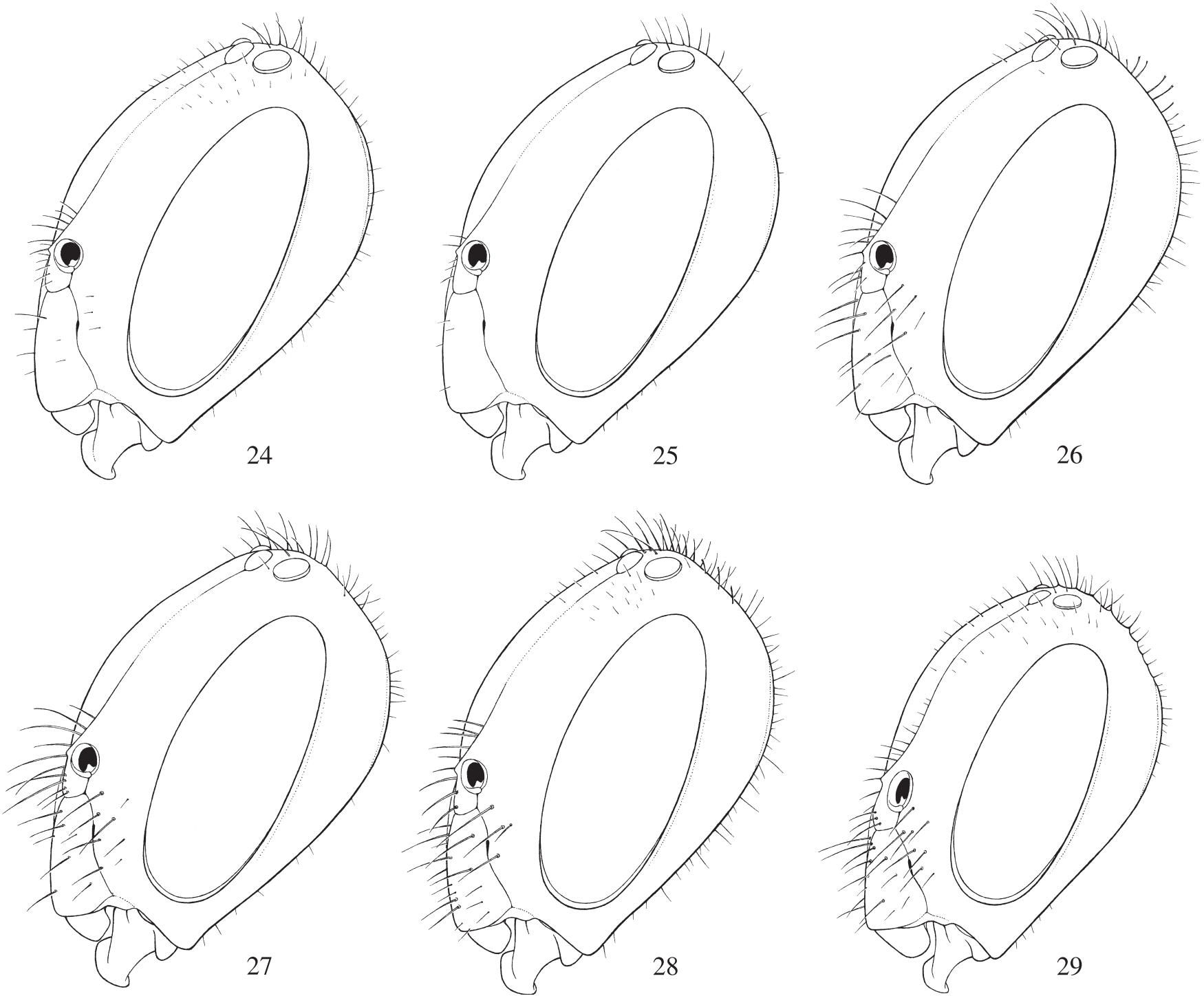

Figs. 24-29. Dolichotrigona, cerdas eretas da cabeça. 24, D. longitarsis; 25, D. mendersoni sp. nov.; 26, D. tavaresi sp. nov.; 27, D. browni sp. nov.; 28, D. moratoi $\mathbf{s p}$ nov.; $29, D$. chachapoya sp. nov.

que aquelas do pedicelo (Fig. 19). Área parocular inferior, um pouco abaixo dos alvéolos antenais, com uma cerda ereta, muito grossa e longa, 2,0x mais longa que o diâmetro do $2^{\circ} \mathrm{fl}$., e algumas cerdas eretas, esparsas, mais curtas, sobressaindose à micropilosidade decumbente (como na Fig. 26); na área supra-clipeal, entre os alvéolos antenais, algumas cerdas simples, eretas, um pouco mais curtas e mais grossas que as da base do escapo. As cerdas eretas do clípeo, mais finas que aquelas das áreas paroculares inferiores, um pouco mais longas que o diâmetro do $2^{\circ}$ fl.; na fronte, um pouco mais curtas; no vértice, tão longas, porém mais grossas, quanto aquelas do escapo; no escutelo, as cerdas eretas no bordo posterior, quase tão longas quanto o comprimento deste.

Integumento. Como descrito para o gênero.

Forma e proporções (medidas na Tabela I). Cabeça 1,14x mais larga que longa e 1,27x mais larga que a distância clipeocelar. Olhos 2,15x mais longos que largos, levemente convergentes embaixo. Área malar 1,33x mais longa que o diâmetro do $2^{\circ} \mathrm{fl}$. Clípeo $0,47 \mathrm{x}$ mais curto que sua largura máxima e $0,26 \mathrm{x}$ a distância clipeocelar. Mandíbulas $0,55 \mathrm{x}$ a distância clipeocelar; com 2 dentículos, o do canto interno muito reduzido (como na Fig. 9, mandíbula inteira). Labro com depressão mediana longitudinal suave. Escapo 1,09x a distância alveolocelar, um pouco achatado medianamente. $\mathrm{O} 1^{\circ} \mathrm{fl}$. tão longo quanto largo (Fig. 19). Distância interocelar 1,09x maior que a ocelorbital e 2,18x o diâmetro do ocelo médio. Escutelo $0,48 \mathrm{x}$ mais curto que largo. Tíbia III quase tão longa quanto a largura da cabeça, e 4,00x mais longa que larga. Basitarso III 2,18x mais longo que largo; o canto póstero-distal em ângulo agudo. Asa anterior ca. 2,42x mais longa que larga, e 1,87x mais longa que a largura da cabeça. Veia $\mathrm{M}$ levemente arqueada (como na Fig. 37). 
Material-tipo. Holótipo, operária, de "BRASIL, Rondônia, Nova Mamoré", "115 - 13/09/96, S10²3.832’ W6500.467', Brown, Boina, Vieira"; parátipos, 21 operárias, de: BRASIL. Rondônia: Guajará-Mirim, 1045.516'S, 64²42.761'W, 09.X.1996, Brown, Boina, Vieira (5 ops., 1913, 1919, 1920, 1921, 1922); Mirante da Serra, $11^{\circ} 10.076^{\prime}$ 'S, 62 ${ }^{\circ} 53.104$ 'W, 25.IX.1996, Brown, Boina, Vieira (1 op., 2412); ibidem, idem, $11^{\circ} 4.356^{\prime} \mathrm{S}, 6^{\circ} 54.673^{\prime} \mathrm{W}$, 04.III.1997 (1 op., 6041); ibidem, idem, Linha 72, $11^{\circ} 10^{\prime} 17.4^{\prime \prime S}, 62^{\circ} 40^{\prime} 0.1^{\prime \prime} \mathrm{W}, 20$. VIII.1997 (1 op., RO-13402); ibidem, idem, Linha $76,11^{\circ} 5^{\prime} 18.9^{\prime \prime} \mathrm{S}, 62^{\circ} 50^{\prime} 29.6^{\prime \prime} \mathrm{W}$, 30.VIII.1997 (2 ops., RO-14005, 14007); Nova Mamoré, 10²3.832'S, $65^{\circ} 0.467^{\prime} \mathrm{W}, 13 . \mathrm{IX} .1996$, Brown, Boina, Vieira (2 ops., 116, 121), Porto Velho, 12-22.X.1966, Camargo (6 ops.); São Miguel do Guaporé, Reserva Indígena Rio Branco, $11^{\circ} 56.132^{\prime}$ S, $62^{\circ} 43.033^{\prime} \mathrm{W}, 23 . I V .1997$, Brown, Boina, Vieira (2 ops., RO-8199, 8252); ibidem, idem, Linha

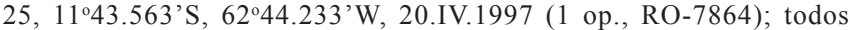
depositados na RPSP.

Material examinado. BRASIL. Rondônia: Costa Marques, estrada 478, 12²6'5.2"S, 64²0'2.6"W, 19.XI.1996, Brown, Boina, Vieira (2 ops., RO-3285, 3286, RPSP); Cujubim, Linha 14, 9²0.154'S, 62033.110'W, 24.III.1997, Brown, Boina, Vieira (5 ops., RO-6696, 6697, 6699, 6702, 6704, RPSP); ibidem, idem, Linha C2, 9²3.205'S, 62³4.854'W, 25.III.1997 (1 op., RO-7170, RPSP); F. P. da Beira [prov. Príncipe da Beira], 7.XI.1961, F. M. Oliveira (4 ops., RPSP); Guajará-Mirim, $10^{\circ} 45.516^{\prime} \mathrm{S}, 6^{\circ} 42.761^{\prime} \mathrm{W}, 09 . X .1996$, Brown, Boina, Vieira (1 op., 1915, RPSP); Machadinho, 9²6.948'S, 61'51.445'W, 21.III.1997, Brown, Boina, Vieira (1 op., RO-6497, RPSP); Ouro Preto D'Oeste, 13.XI.1987, C. Elias, Polonoroeste (1op., DZUP); ibidem, $10^{\circ} 42.252^{\prime}$ 'S, 62 $22.075^{\prime \prime} \mathrm{W}, 10 . \mathrm{I} .1997$, Brown, Boina, Vieira (1 op., 4884, RPSP); Porto Velho, 12-22.X.1966, Camargo (1 op., RPSP); Vilhena, 22.VII-5.VIII.1983, F. J. A. Peralta (4 ops., INPA); ibidem, 6.XII.1986, C. Elias, Polonoroeste, planta 9, meta 5, 8-10 am (1 op., DZUP);

Distribuição geográfica e hábitat. Só conhecida de Rondônia, Brasil (Fig. 44).

\section{Nidificação. Desconhecida.}

Etimologia. O nome da espécie é uma homenagem ao Marechal Cândido Mariano da Silva Rondon, pelo papel pioneiro junto às populações indígenas, salvaguardando o tratamento pacífico, por ocasião das diversas expedições pelo interior do Brasil, por ele chefiadas, para implantação das linhas telegráficas, e das quais também resultaram inestimáveis contribuições ao conhecimento da etnografia, geologia, botânica e zoologia.

Discussão. A presença de cerdas longas no $1^{\circ} \mathrm{fl}$., combinada com as cerdas longas e robustas no escapo, pedicelo e áreas paroculares inferiores e a condição bidentada das mandíbulas, sendo o dente interno muito pequeno, permitem reconhecer D. rondoni $\mathbf{s p . ~ n o v . ~ d e n t r e ~ a s ~ d e m a i s ~ e s p e ́ c i e s ~ d o ~ g e ̂ n e r o . ~ P e l a ~}$ forma dos dentes da mandíbula e pelas cerdas dos escapo e paroculares inferiores, assemelha-se mais a $D$. tavaresi $\mathbf{s p .}$ nov., da qual separa-se pela presença de cerdas mais longas e robustas no $1^{\circ} \mathrm{fl}$. (em D. tavaresi $\mathbf{s p . ~ n o v . , ~ a s ~ c e r d a s ~ d o ~} 1^{\circ} \mathrm{fl}$. são mais curtas que metade do diâmetro deste ou ausentes, Fig. 20), e pelo último fl., apenas com o ápice amarelado (em $D$. tavaresi sp. nov., mais da metade apical ou por inteiro amarelado). Outra espécie que também apresenta cerdas mais longas e robustas no $1^{\circ}$ fl. é $D$. moratoi sp. nov., nesta, entretanto, cujas mandíbulas também são bidentadas, o dente interno é muito grande (Fig. 12), e as cerdas da base do escapo são muito longas (Fig. 22), ca. 3x o diâmetro deste, ou mais (em D. rondoni sp. nov., 1-2,0x).

\section{Dolichotrigona tavaresi sp. nov.} (Figs. 10, 20, 26, 39-43, 44; Tabela II)

Diagnose. Operária. Largura da cabeça entre 1,36-1,46, comprimento da asa anterior, ca. 2,67-2,97; mandíbula com 2 dentículos, o dente do canto interno um pouco recuado (Fig. 10); escapo normal (Fig. 20), 1,1x a distância alveolocelar; $1^{\circ} \mathrm{fl}$. longo, comprimento aproximadamente igual à sua largura (Fig. 20); cerdas eretas do escapo, robustas e relativamente longas, distribuídas desde a base até o ápice, na base, um pouco mais longas, ca. 1,5-2x o diâmetro do escapo (Fig. 20); pedicelo com cerdas eretas, tão longas ou um pouco mais que o diâmetro deste; o $1^{\circ} \mathrm{fl}$. sem cerdas eretas ou com cerdas muito curtas, menores que metade do diâmetro deste (Fig. 20); área parocular inferior, próxima a porção inferior dos alvéolos antenais, com pelo menos uma cerda muito grossa e longa, ca. 1,5x o diâmetro do $2^{\circ}$ fl. (Fig. 26); cerdas do bordo posterior do escutelo ca. 0,9-1,0x o comprimento deste; membrana das asas hialina.

Holótipo, operária (Figs. 10, 26, holótipo; Fig. 20, parátipo; Tabela II).

Dimensões. Comprimento total aproximado, 3,03; da asa anterior, 2,75 (incluindo a tégula, 3,06); largura máxima da cabeça, 1,42; do TIII, 1,06.

Cor do integumento. Preto; áreas paroculares inferiores, áreas malares, mandíbulas, escapo, pedicelo e $1^{\circ} \mathrm{fl}$., basitarso e tarsômeros de todas as pernas, ferrugíneos; último fl. por inteiro amarelo; margem e região discal das tégulas e margem dos TIV-TV, translúcidas. Membrana das asas hialina; microtríquias fuscas; veias méleas.

Pilosidade. Escapo com cerdas longas, eretas, esparsas, distribuídas da base até o ápice, exceto na face interna; na base ca. $2 \mathrm{x}$ o diâmetro do escapo e progressivamente mais curtas em direção ao ápice (como na Fig. 20); no pedicelo as cerdas mais curtas que o diâmetro deste (no parátipo no 860396 ca. $1,5 \mathrm{x}$ o diâmetro deste, Fig. 20 ); $1^{\circ}$ fl. com 1 cerda ereta, muito curta, menor que metade do diâmetro deste. Área parocular inferior, um pouco abaixo dos alvéolos antenais, com algumas cerdas eretas robustas, um pouco mais curtas que aquelas da base do escapo, e ca. 1,3x o diâmetro do $2^{\circ} \mathrm{fl}$., sobressaindo-se à micropilosidade decumbente; na área supraclipeal e entre os alvéolos antenais, as cerdas eretas um pouco mais longas e mais grossas que as da base do escapo. As cerdas eretas do clípeo, mais finas que aquelas das áreas paroculares inferiores e um pouco mais longas que o diâmetro do escapo; na fronte, um pouco mais curtas; no vértice, as mais longas com 0,12 ; na região pré-occipital um pouco mais curtas; no disco do mesoscuto, 0,06; no escutelo, as cerdas eretas no bordo posterior quase tão longas quanto o comprimento deste. 


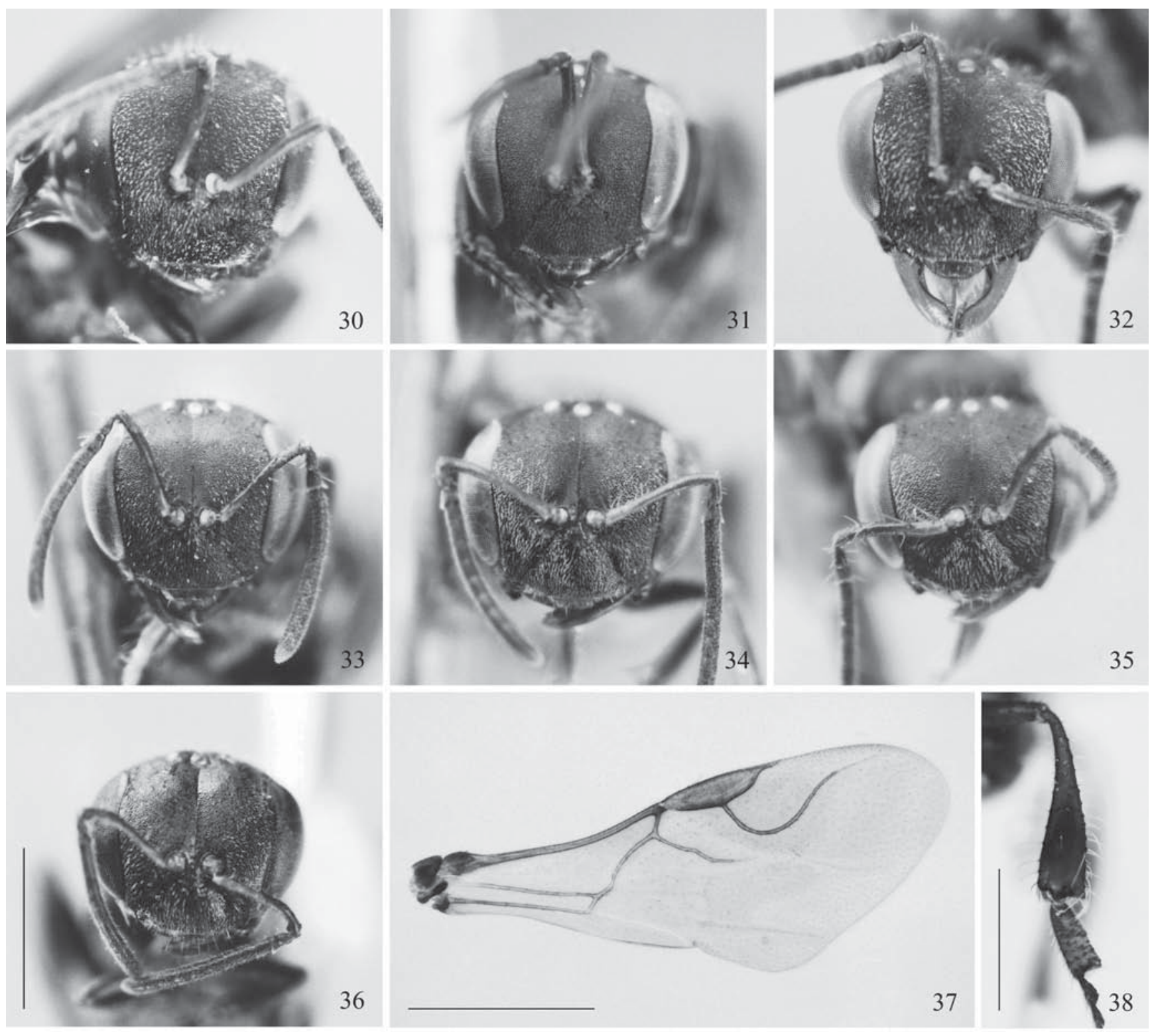

Figs. 30-38. Dolichotrigona. 30, D. schulthessi (Potrero Grande, Costa Rica); 31, D. mendersoni sp. nov., holótipo; 32, D. clavicornis sp. nov., holótipo; 33, D. rondoni sp. nov., parátipo (Mirante da Serra, RO, Brasil, n 6041); 34, D. browni sp. nov., parátipo (Nova União, RO, ${ }^{\circ} 4402$ ); 35, D. moratoi sp. nov., parátipo (Parque Nacional Serra do Divisor, AC, Brasil, n 971025); 36, D. chachapoya sp. nov., holótipo; 37, D. longitarsis, asa anterior; 38, D. longitarsis, perna III. Escalas $=1,0 \mathrm{~mm}$ (Figs. 30-36, na mesma escala).

Integumento. Como descrito para o gênero.

Forma e proporções (medidas na Tabela II). Cabeça 1,15x mais larga que longa e 1,29x mais larga que a distância clipeocelar. Olhos 2,30x mais longos que largos, levemente convergentes embaixo. Área malar 1,33x mais longa que o diâmetro do $2^{\circ} \mathrm{fl}$. Clípeo $0,44 \mathrm{x}$ mais curto que sua largura máxima e 0,29x a distância clipeocelar. Mandíbulas 0,56x a distância clipeocelar; com dois dentes nítidos, separados por amplo espaço em V aberto (Fig. 10). Labro com uma depressão mediana longitudinal nítida. Escapo 1,12x a distância alveolocelar, um pouco achatado medianamente. $\mathrm{O} 1^{\circ} \mathrm{fl}$. tão longo quanto largo (Fig. 20). Distância interocelar 1,18x maior que a ocelorbital e 2,36x o diâmetro do ocelo médio. Escutelo
$0,42 \mathrm{x}$ mais curto que largo. Tíbia III tão longa quanto a largura da cabeça, e 3,94x mais longa que larga. Basitarso III 2,36x mais longo que largo; canto póstero-distal formando ângulo quase reto em relação à margem posterior. Asa anterior ca. $1,94 \mathrm{x}$ mais longa que a largura da cabeça, um pouco dobrada na largura. Veias e hâmulos como descritos para o gênero. Veia M levemente arqueada (como na Fig. 37).

Macho (Figs. 39-43; Tabela II).

Dimensões. Comprimento total aproximado, 3,87 ; da asa anterior, 2,88 (incluindo a tégula, 3,18); largura máxima da cabeça, 1,40; TIII, amassado. 
Cor do integumento. Como na operária, exceto último fl., por inteiro enegrecido.

Pilosidade. No geral, com cerdas mais curtas e finas que na operária. Cerdas do escapo curtas, finas e ralas, menores que metade do diâmetro do escapo; pedicelo com 2 cerdas eretas, muito curtas, ca. $0,33 \mathrm{x}$ do diâmetro deste; $1^{\circ} \mathrm{fl}$. com uma cerda muito curta, ca. $0,2 \mathrm{x}$ o diâmetro deste; área parocular inferior, um pouco abaixo dos alvéolos antenais, com uma cerda ereta, curta e fina, ca. $0,6 \mathrm{x}$ o diâmetro do $2^{\circ} \mathrm{fl}$; área supra-clipeal recoberta pelos escapos; no clípeo e fronte, as cerdas eretas curtas, ca. 0,6x o diâmetro do $2^{\circ}$ fl.; no vértice, mais longas, ca. 2x o diâmetro do $2^{\circ}$ fl.; no escutelo, as cerdas eretas do bordo posterior, quase tão longas quanto o comprimento deste.

Integumento. Como na operária.

Forma e proporções (medidas na Tabela II). Cabeça 1,13x mais larga que longa e 1,30x mais larga que a distância clipeocelar. Olhos 2,17x mais longos que largos, convergentes embaixo. Área malar muito curta, $0,2 \mathrm{x}$ o diâmetro do $2^{\circ} \mathrm{fl}$. Clípeo $0,57 \mathrm{x}$ mais curto que sua largura máxima e $0,30 \mathrm{x}$ a distância clipeocelar. Mandíbulas 0,42x a distância clipeocelar; um pouco fechadas, aparentemente sem dentes. Labro sem depressão mediana longitudinal. Escapo curto, 0,79x a distância alveolocelar, um pouco alargado medianamente. Os fls. basais da antena, cilíndricos, não achatados como na operária; o $1^{\circ} \mathrm{fl}$. curtíssimo, o comprimento $0,33 \mathrm{x}$ sua largura. Distância interocelar 1,63x maior que a ocelorbital e 1,63x o diâmetro do ocelo médio. Escutelo $0,45 \mathrm{x}$ mais curto que largo. Tíbia III mais curta, $0,91 x$ a largura da cabeça e 3,46x mais longa que larga. Basitarso III 2x mais longo que largo; o canto póstero-distal em ângulo agudo. Asa anterior ca. 2,06x mais longa que a largura da cabeça, dobrada na largura. Veias das asas como na operária. Genitália e esternos pré-genitais como nas Figs. 3943.

Nota. O exemplar foi incluído, tentativamente, em $D$. tavaresi sp. nov., por ter sido coletado junto com operárias desta espécie, na mesma data e localidade, e por apresentar algumas cerdas eretas no clípeo, áreas paroculares, fronte e disco do mesoscuto. Nessa mesma região também foi coletada uma operária de $D$. mendersoni $\mathbf{s p}$. nov., que ao contrário de $D$. tavaresi sp. nov., não apresenta cerdas eretas na face.

Material-tipo. Holótipo, operária, de "Rio Ipixuna Purus - AM Brasil, 16,19-I-1986, 860444”, “SB.20, 6325'W - 605'S, Camargo Mazucato"; parátipos, 9 operárias, com as mesmas etiquetas do holótipo, diferindo apenas no número de registro, 860359 ( 2 por alfinete), $860396,860447,860462$ (2 por alfinete), 860465, 860466 (2 por alfinete); todos depositados na RPSP.

Material examinado. BRASIL. Amazonas: Rio Ipixuna, Purus, SB.20, 6325'W, 605'S, 16-19.I.1986, Camargo, Mazucato (1 macho, 860465, RPSP); Acre: Parque Nacional Serra do Divisor, Rio das Minas, Sítio 6, 08³3’30"S, 7253’30"W, 19.III.1997, E. F. Morato (1 op., 972710, RPSP).
Distribuição geográfica e hábitat. Arredores do rio Ipixuna - Purus, AM, até AC, Brasil.

Nidificação. Desconhecida.

Etimologia. O nome da espécie é uma homenagem a José Amílcar Tavares Filho, Técnico do Depto. de Biologia da FFCLRP, pela dedicação nos serviços de preparação e triagem de material, atualização dos fichários de Meliponini, e nos cuidados com a coleção de abelhas (RPSP).

Discussão. Muito semelhante a D. rondoni sp. nov., da qual distingue-se apenas pela ausência de cerdas longas no $1^{\circ} \mathrm{fl}$., pelo último fl. amarelo e depressão mediana longitudinal do labro mais marcada.

\section{Dolichotrigona browni sp. nov.}

(Figs. 11, 21, 27, 34, 44; Tabela II)

Diagnose. Operária. Largura da cabeça entre 1,44-1,52, comprimento da asa anterior, ca. 2,67-3,15; mandíbula com 2 dentes grandes, o dente do canto interno pontiagudo (Fig. 11); escapo normal (Fig. 21), 1,1x a distância alveolocelar; $1^{\circ} \mathrm{fl}$. longo, comprimento aproximadamente igual a sua largura (Fig. 21); escapo com cerdas eretas, robustas e relativamente longas, distribuídas aproximadamente nos $2 / 3$ basais, ca. 2 x o diâmetro do escapo, no terço apical praticamente sem cerdas eretas (Fig. 21); pedicelo com cerdas eretas, tão longas ou um pouco mais curtas que o diâmetro deste (Fig. 21); o $1^{\circ}$ fl. sem cerdas eretas ou com cerdas muito curtas, menores que metade do diâmetro deste (Fig. 21); área parocular inferior, próxima a porção inferior dos alvéolos antenais, com pelo menos uma cerda muito grossa e longa, ca. 1,0-1,5x o diâmetro do $2^{\circ}$ fl. (Fig. 27); cerdas do bordo posterior do escutelo ca. 0,9-1,0x o comprimento deste; membrana das asas hialina.

Holótipo, operária (Figs. 11, 21, 27, holótipo; Fig. 34, parátipo; Tabela II).

Dimensões. Comprimento total aproximado, 3,21; da asa anterior, 2,88 (incluindo a tégula, 3,27); largura máxima da cabeça, 1,48; do TIII, 1,17 .

Cor do integumento. Preto; apenas os $2 / 3$ basais do escapo e ápice do último fl. da antena, castanho-amarelados, e as mandíbulas, ferrugíneas; as pernas, castanho-escuras; margem e região discal das tégulas, translúcidas. Membrana das asas hialina; microtríquias fuscas; veias méleas.

Pilosidade. Cerdas do escapo longas, eretas, robustas, concentradas principalmente nos $2 / 3$ basais, na base, mais longas, ca. 2x o diâmetro deste, no terço apical as cerdas eretas ausentes (Fig. 21); pedicelo com 3 cerdas eretas, pouco menores que o diâmetro deste; $1^{\circ}$ fl. com uma cerda ereta, pouco menor que o diâmetro deste (Fig. 21). Área parocular inferior, um pouco abaixo dos alvéolos antenais, com 3-4 


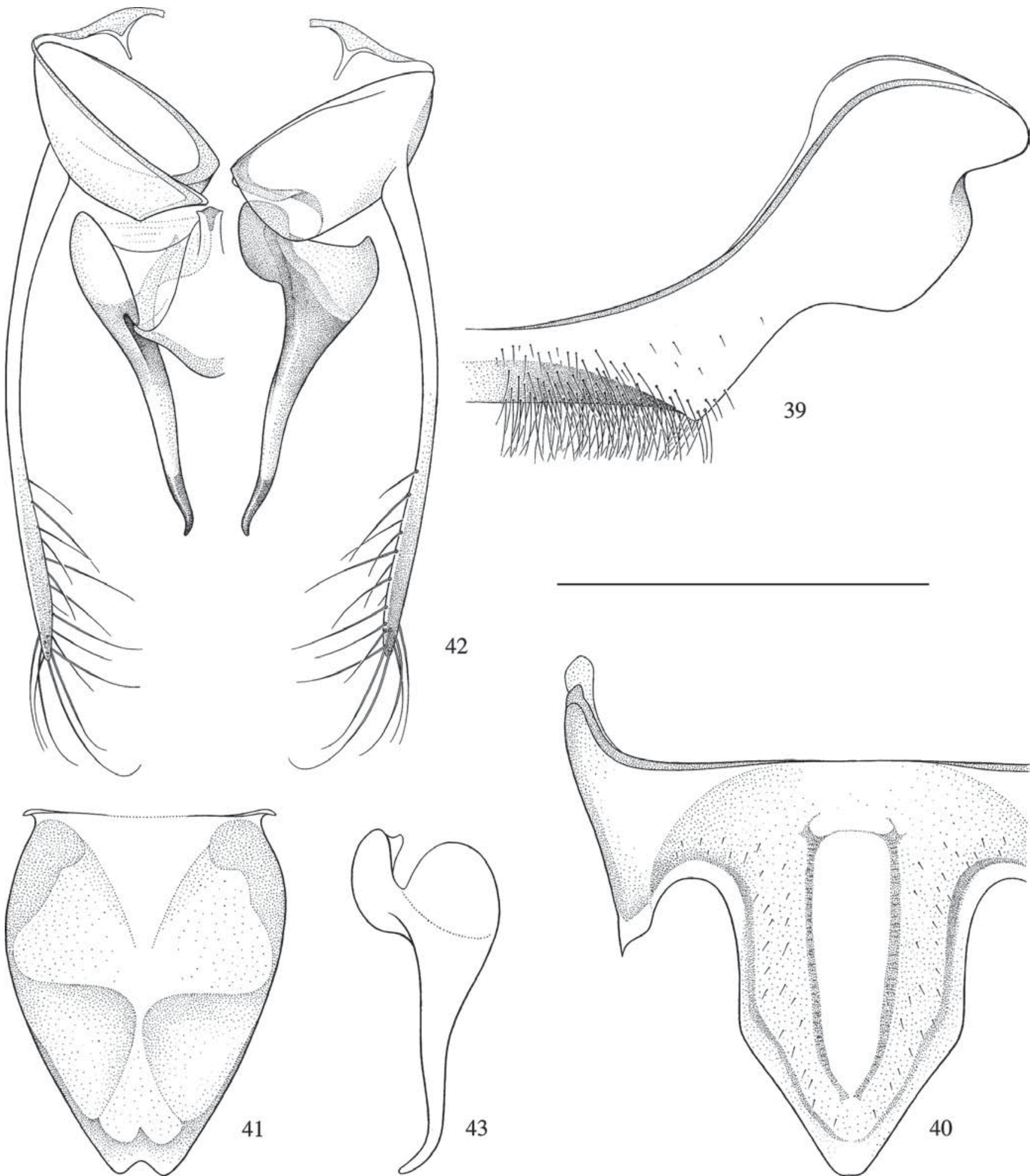

Figs. 39-43. Dolichotrigona tavaresi sp. nov., macho. 39, esterno VI; 40, esterno VII; 41, esterno VIII; 42, genitália, vista dorsal e ventral, respectivamente; 43, detalhe da valva do edeago, em perfil. Escala $=0,5 \mathrm{~mm}$.

cerdas eretas, muito grossas, aproximadamente tão longas quanto o diâmetro do $2^{\circ}$ fl. (Fig. 27), sobressaindo-se à micropilosidade decumbente; na área supra-clipeal, até um pouco acima da tangente superior dos alvéolos antenais, algumas cerdas simples, longas, mais grossas que aquelas da base do escapo (Fig. 27). As cerdas eretas do clípeo, mais finas que aquelas das áreas paroculares inferiores, e um pouco mais longas que o diâmetro do $2^{\circ}$ fl.; na fronte, mais curtas; no 
vértice, tão longas quanto as do clípeo, e duas cerdas, uma a cada lado, junto à margem interna dos ocelos laterais, mais longas que aquelas do vértice; no escutelo, as cerdas eretas no bordo posterior, quase tão longas quanto o comprimento deste.

\section{Integumento. Como descrito para o gênero.}

Forma e proporções (medidas na Tabela II). Cabeça 1,16x mais larga que longa e 1,30x mais larga que a distância clipeocelar. Olhos 2,25x mais longos que largos, levemente convergentes embaixo. Área malar 1,6x mais longa que o diâmetro do $2^{\circ}$ fl. Clípeo 0,46x mais curto que sua largura máxima e $0,29 \mathrm{x}$ a distância clipeocelar. Mandíbulas $0,56 \mathrm{x}$ a distância clipeocelar; com dois dentes grandes, separados por amplo espaço em $V$ aberto, no terço interno do bordo distal (Fig. 11). Labro com uma depressão mediana longitudinal nítida. Escapo $1,18 \mathrm{x}$ a distância alveolocelar, um pouco achatado medianamente. $\mathrm{O} 1^{\circ} \mathrm{fl}$. tão longo quanto largo (Fig. 21). Distância interocelar 1,04x maior que a ocelorbital e 2,45x o diâmetro do ocelo médio. Escutelo 0,46x mais curto que largo. Tíbia III 0,96x a largura da cabeça, e 3,94x mais longa que larga. Basitarso III 2,5x mais longo que largo; canto póstero-distal em ângulo reto. Asa anterior ca. 1,95x mais longa que a largura da cabeça, um pouco dobrada na largura. Veia M levemente arqueada (como na Fig. 37).

Variação. O que se mantém mais constante nessa espécie é a quase ausência de cerdas eretas no terço apical do escapo, exceto nos exemplares do Equador e Peru, nos quais estas chegam até o ápice do escapo, embora mais curtas que na base, e as cerdas da cabeça, de um modo geral, são mais delgadas que aquelas dos exemplares de Rondônia. Nestes, as cerdas da área supra-clipeal, até um pouco acima dos alvéolos antenais, variam em comprimento, de 1-3x o diâmetro do escapo. No exemplar de Cáceres-MT, as cerdas eretas são mais curtas na cabeça, especialmente no escapo $(0,88 \mathrm{x}$ o diâmetro deste), e tórax, mas os dentes da mandíbula são iguais àqueles dos exemplares de Rondônia.

Material-tipo. Holótipo, operária, de "RO-8508 BRASIL. Rondônia

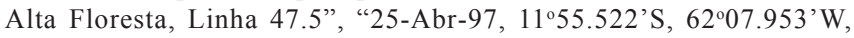
Brown, Boina, Vieira"; parátipos, 15 operárias, sendo 4 com etiquetas de procedência iguais às do holótipo, diferindo apenas no número de registro - $8507,8509,8510,8539$, e outros 11 , das seguintes localidades: BRASIL. Rondônia: Campo Novo, BR-421 oeste de C.N., $10^{\circ} 27^{\prime} 6.1^{\prime \prime S}, 63^{\circ} 51^{\prime} 52.8^{\prime \prime W}$, 11.IX.1997, Brown, Boina, Vieira (1 op., RO-14340); Nova Mamoré, $10^{\circ} 24.410^{\prime} \mathrm{S}, 65^{\circ} 0.406^{\prime} \mathrm{W}, 13 . \mathrm{IX} .1996$, Brown, Boina, Vieira (1 op., 57); Nova União, $10^{\circ} 49.958^{\prime}$ 'S, 62²9.930'W, 19.XII.1996, Brown, Boina, Vieira (3 ops., 4402, 4404,

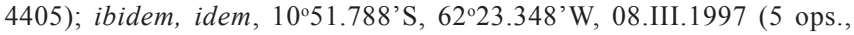

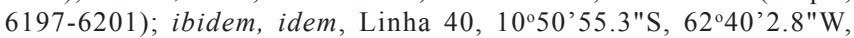
01.IX.1997 (1 op., RO-14100); todos depositados na RPSP.

Material examinado. EQUADOR. Napo: Añangu, 25-30.XI.1987, M. Huybensz (2 ops., 890326, 890327, RPSP); Orellana Tiputini Biodiversity Sta., 7-12.VII.2000, S. Cameron, J. Whitfield (1 op., 43.112, INHS). PERU. Loreto: Napo river, 20.VI.1910, H. Parish (1 op., 43.113, INHS). San Martin: San Antonio de Cumbaza, 06²4,522'S, 76²4,409'W, IV.2003, 415 masl, Claus Rasmussen (2 ops., MUSM); Tarapoto - Yurimaguas road $\mathrm{km} 20$ "BIODIVERSIDAD", 06³4'S, 76²0'W, 950 masl, II.2003, Rasmussen (2 ops., MUSM); Cuzco: Pagoreni, $11^{\circ} 42^{\prime}$ 'S, 72 ${ }^{\circ} 54^{\prime} \mathrm{W}, 465 \mathrm{~m}$, 12.V.1998, Proyecto Camisea Cmtb. (1 op., MUSM); Madre de Dios: Pto. Maldonado, 31.IX.1962, Luis Peña (4 ops., DZUP); Tambopata, Tambopata Jungle Lodge, 225 m.a.s.1. S12 49,456, W69 24,163, 920.X.2001, C. Rasmussen (1 op., MUSM). BRASIL. Acre: Plácido de Castro, 20.IX.1994, E. F. Morato (2 ops., INPA); Reserva Estrat. [sic $=$ Extrat.] Boa Esperança, Porto Dias, 11.XII.1994, F. J. A. Peralta (1 op., INPA); Rio Branco, 2.V.2000, M. J. Thomazini, pimenta longa, Piper hispidinervium, espiguetas (1 op., 001382, RPSP). Rondonia: Alta Floresta, Linha 47.5, $11^{\circ} 55.522^{\prime} \mathrm{S}, 62^{\circ} 7.953^{\prime} \mathrm{W}$, 25.IV.1997, Brown, Boina, Vieira (5 ops., RO-8507-10, 8539, RPSP); Cujubim, Reserva Rio Cujubim, 9⒛308'S, 62³4.440'W, 24.III.1997, Brown, Boina, Vieira (1 op., RO-6921, RPSP); ibidem, idem, Linha 14, 9²0.154'S, 62³3.110'W, 24.III.1997 (3 ops., RO$6671,6677,6790, \quad$ RPSP); Guajará-Mirim, $10^{\circ} 33.751^{\prime} \mathrm{S}$, 64²5.463'W, 09.IX.1996, Brown, Boina, Vieira (3 ops., 745, 761, 766, RPSP); Ig. Tracoazinho, reg. Campo Novo, 1-15.VIII.1985, V. Py-Daniel, L. Aquino (4 ops., INPA); Montenegro, Estrada a Buritis, $10^{\circ} 20^{\prime} 43.9^{\prime \prime}$ S, 63²6'10.4"W, 09.IX.1997, Brown, Boina, Vieira (1 op., RO-14173, RPSP); Nova Califórnia, Linha Pioneiros, 947'56.7"S, 66³6'10.7"W, 25.VI.1997, Brown, Boina, Vieira (1 op., RO-11078, RPSP); Nova Mamoré, $10^{\circ} 24.410^{\prime} \mathrm{S}, 65^{\circ} 0.406^{\prime} \mathrm{W}$, 13.IX.1996, Brown, Boina, Vieira (1 op., 64, RPSP); Ouro Preto D'Oeste, 24.VIII.1987, C. Elias, Projeto Polonoroeste (1 op., DZUP); ibidem, idem, 22.IX.1987 (1 op., DZUP); Pimenta Bueno, Guaporé, XI.1960, A. Alvarenga (1 op., 43.117, INHS); Rolim de Moura,

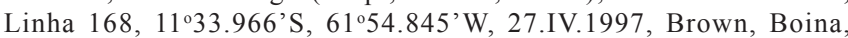
Vieira (1 op., RO-8809, RPSP); São Miguel do Guaporé, Reserva Indígena Rio Branco, $11^{\circ} 56.132^{\prime} \mathrm{S}, 62^{\circ} 43.033^{\prime} \mathrm{W}, 23 . \mathrm{IV} .1997$, Brown, Boina, Vieira (1 op., RO-8300, RPSP). Mato Grosso: Cáceres, 27.XII.1984, C. Elias, Polonoroeste (1 op., DZUP); BOLÍVIA. sem localidade especificada, apenas "Bolivia" (1 op., 11864, MACN); $\boldsymbol{L a}$

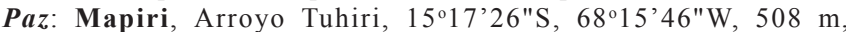
12.IV.2004, M. Hauser (1 op., MUSM); El Beni: Loreto, Marban, XI.1962, N. kempff $[$ sic $=$ Kempff] Mercado (3 ops., DZUP).

Distribuição geográfica e hábitat. Sudoeste da Amazônia, AC, RO, MT, Brasil, Equador, Peru, Bolívia (Fig. 44).

\section{Nidificação. Desconhecida.}

Etimologia. O nome da espécie é uma homenagem a John Christopher Brown, coletor da espécie, que desenvolveu coletas sistemáticas de Meliponini em Rondônia e pela doação de todos os espécimens à RPSP .

Discussão. Pelos dentes das mandíbulas, grandes, assemelha-se mais a $D$. moratoi $\mathbf{s p}$. nov., da qual distingue-se pelas cerdas mais curtas na base do escapo, pedicelo e, especialmente, no $1^{\circ} \mathrm{fl}$., e pela quase ausência de cerdas no terço apical do escapo (Figs. 21, 22).

\section{Dolichotrigona moratoi sp. nov.}

(Figs. 12, 22, 28, 35, 44; Tabela II)

Diagnose. Operária. Largura da cabeça entre 1,44-1,52, comprimento da asa anterior, ca. 2,79-2,94; mandíbula com 2 dentes grandes, o dente do canto interno pontiagudo (Fig. 12); escapo normal (Fig. 22), 1,1 $\mathrm{x}$ a distância alveolocelar; $1^{\circ} \mathrm{fl}$. longo, comprimento aproximadamente igual à sua largura (Fig. $22)$; cerdas da base do escapo muito longas e robustas, $2-3 \mathrm{x}$ 

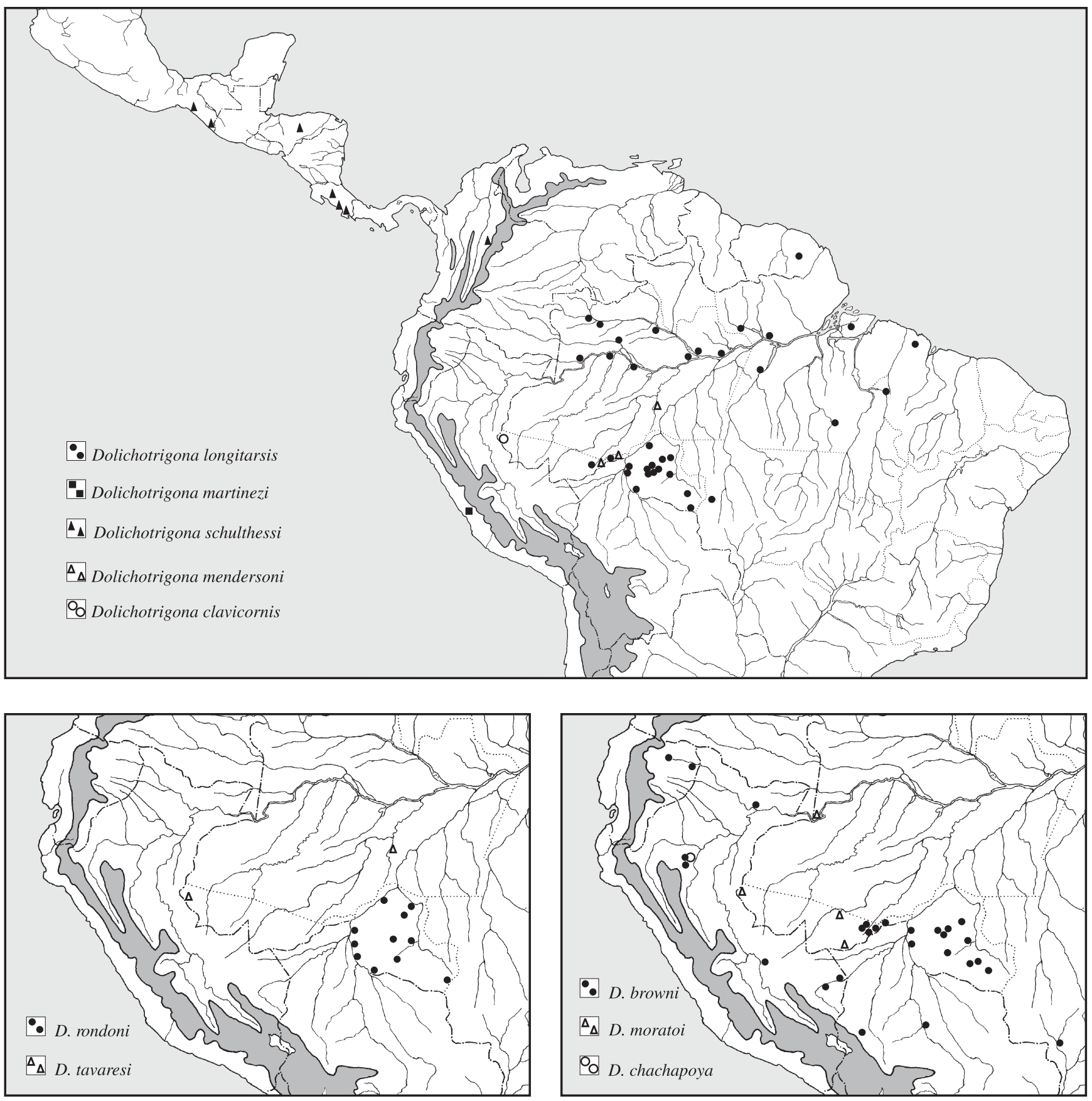

Fig. 44. Dolichotrigona. Registros de ocorrência das espécies (a informação sobre a ocorrência de D. schulthessi no México - as duas localidades assinaladas no mapa - foi extraída de Ayala, 1999).

mais longas que o diâmetro deste, um pouco mais curtas em direção ao ápice (Fig. 22); pedicelo e $1^{\circ} \mathrm{fl}$. com cerdas eretas, mais longas que o diâmetro destes (Fig. 22); área parocular inferior, próxima a porção inferior dos alvéolos antenais, com duas ou mais cerdas muito grossas e longas, 2,0x maiores que o diâmetro do $2^{\circ}$ fl. (Fig. 28); cerdas do bordo posterior do escutelo ca. 0,9-1,1 x o comprimento deste; membrana das asas hialina.

Holótipo, operária (Figs. 12, 22, 28, holótipo; Fig. 35, parátipo; Tabela II).
Dimensões. Comprimento total aproximado, 3,24; da asa anterior, 2,85 (incluindo a tégula, 3,18); largura máxima da cabeça, 1,50; do TIII, 1,20.

Cor do integumento. Preto, apenas a mandíbula castanhoferrugínea, e base do escapo e último fl. quase por inteiro, amarelados; margem da tégula translúcida. Membrana das asas hialina; microtríquias castanhas; veias méleas.

Pilosidade. Cerdas da base do escapo muito longas, $3,25 \mathrm{x}$ 
o diâmetro deste; para o ápice, um pouco mais curtas, com ca. 1,63x o diâmetro deste; pedicelo com 4-5 cerdas, eretas, maiores que o diâmetro deste; $1^{\circ} \mathrm{fl}$. com 3-4 cerdas eretas, como aquelas do pedicelo (Fig. 22, 35). Área parocular inferior, um pouco abaixo dos alvéolos antenais, com algumas cerdas eretas, muito grossas e longas, ca. $2 \mathrm{x}$ mais longas que o diâmetro do $2^{\circ} \mathrm{fl}$., sobressaindo-se à micropilosidade decumbente (Fig. 28); na área supra-clipeal, entre os alvéolos antenais, algumas cerdas simples, eretas, mais curtas e mais grossas que as da base do escapo (Fig. 28). As cerdas eretas do clípeo um pouco mais curtas e mais finas que aquelas das áreas paroculares inferiores e um pouco mais longas que o diâmetro do $2^{\circ} \mathrm{fl}$.; na fronte mais curtas; no vértice, mais finas e ca. metade do comprimento daquelas da base do escapo; no escutelo, as cerdas eretas no bordo posterior, $1,05 \mathrm{x}$ mais longas que o comprimento deste.

Integumento. Como descrito para o gênero.

Forma e proporções (medidas na Tabela II). Cabeça 1,17x mais larga que longa e 1,32x mais larga que a distância clipeocelar. Olhos 2,24x mais longos que largos, levemente convergentes embaixo. Área malar 1,33x mais longa que o diâmetro do $2^{\circ}$ fl. Clípeo $0,47 x$ mais curto que sua largura máxima e $0,27 \mathrm{x}$ a distância clipeocelar. Mandíbulas $0,56 \mathrm{x}$ a distância clipeocelar; com dois dentes grandes, separados por amplo recorte em $\mathrm{V}$ aberto, o do canto interno, pontiagudo (Fig. 12). Labro com depressão mediana nítida. Escapo 1,09x a distância alveolocelar, um pouco achatado medianamente. $\mathrm{O} 1^{\circ} \mathrm{fl}$. tão longo quanto largo (Fig. 22). Distância interocelar 1,17x maior que a ocelorbital e 2,55x o diâmetro do ocelo médio. Escutelo $0,42 \mathrm{x}$ mais curto que largo. Tíbia III ca. $0,96 \mathrm{x}$ mais curta que a largura da cabeça, e 3,89x mais longa que larga. Basitarso III 2,42x mais longo que largo; canto póstero-distal em ângulo agudo. Asa anterior ca. 2,38x mais longa que larga, e 1,90x mais longa que a largura da cabeça. Veia $\mathrm{M}$ levemente arqueada (como na Fig. 37).

Material-tipo. Holótipo, operária, de "BRASIL, Acre, Parque Nacional Serra do Divisor, 07²6’36"S - 7340’28"W”, “10/XI/1996, E. F. Morato, Morro Queimado, Sítio 1, no. 971023"; parátipos, 4 operárias, com as mesmas etiquetas de procedência, diferindo apenas nos números de registro: 970637, 970862, 971024, 971025; todos depositados na RPSP.

Material examinado. BRASIL. Amazonas: Tabatinga, X.1958, F. M. Oliveira (6 ops., DZUP); Acre: Brasiléia, S. [?] Porongaba, 30.X.1993, M. L. Oliveira (1 op., INPA); Parque Nacional Serra do Divisor, Morro Queimado, Sítio 1, 07²6’36"S, 7340’28"W", 10.XI.1996, E. F. Morato (1 op., 971022, INPA), Sena Madureira, Rio Caeté, 6840’4,8"W, 0903'14,4"S, 03.IV.1994, E. F. Morato (1 op., INPA).

Distribuição geográfica e hábitat. Conhecida apenas dos estados do Amazonas e Acre, Brasil (Fig. 44).

Nidificação. Desconhecida.

Etimologia. O nome da espécie é uma homenagem a Elder Ferreira Morato, da Universidade Federal do Acre, Rio Branco-
AC, pela sua contribuição ao conhecimento sobre a diversidade de abelhas-sem-ferrão no estado do Acre, Brasil, onde realizou inúmeras coletas.

Discussão. As cerdas muito longas na base do escapo, áreas paroculares inferiores, pedicelo e $1^{\circ} \mathrm{fl}$., e o último fl. predominantemente amarelo, combinados com a presença de dois dentes grandes na mandíbula, permite reconhecer $D$. moratoi sp. nov. dentre as demais espécies do gênero. Pela forma dos dentes da mandíbula, assemelha-se mais a $D$. browni sp. nov., nesta porém, o $1^{\circ} \mathrm{fl}$. apresenta cerdas muito curtas, além da pilosidade mais curta na base do escapo, e praticamente ausente no terço apical; já na área supra-clipeal e entre os alvéolos antenais, por outro lado, as cerdas são, geralmente, mais robustas e bem mais longas que em $D$. moratoi sp. nov., e o último fl. é predominantemente enegrecido.

\section{Dolichotrigona chachapoya sp. nov.}

(Figs. 13, 23, 29, 36, 44; Tabela II)

Diagnose. Operária. Largura da cabeça entre 1,29-1,33, comprimento da asa anterior, ca. 2,55-2,67; mandíbula com 2 dentículos, o do canto interno arredondado (Fig. 13); escapo fortemente achatado próximo a base e curvado no ápice (Fig. 23), $1,1 \mathrm{x}$ a distância alveolocelar; $1^{\circ} \mathrm{fl}$. curto, comprimento ca. metade de sua largura (Fig. 23); cerdas eretas do escapo presentes desde a base até próximo ao ápice, na base um pouco mais longas que o diâmetro do deste, um pouco mais curtas em direção ao ápice (Fig. 23); cerdas do pedicelo e $1^{\circ} \mathrm{fl}$. mais curtas que o diâmetro destes (Fig. 23); área parocular inferior, próxima a porção inferior dos alvéolos antenais, com algumas cerdas robustas, ca. 2,0x mais longas que o diâmetro do $2^{\circ} \mathrm{fl}$. (Fig. 29); cerdas do bordo posterior do escutelo aproximadamente tão longas quanto o comprimento deste; membrana das asas hialina.

\section{Holótipo, operária (Figs. 13, 23, 29, 36; Tabela II).}

Dimensões. Comprimento total aproximado, 2,91; da asa anterior, 2,67 (incluindo a tégula, 3,00); largura máxima da cabeça, 1,33; do TIII, 1,08.

Cor do integumento. Preto, apenas as mandíbulas, metade basal dos escapos e tarsômeros de todos os pares de pernas, ferrugíneos; ápice do último fl., margem e região discal das tégulas, e margem dos TV e TVI, translúcidos. Membrana das asas hialina; microtríquias enegrecidas; veias méleo-claras.

Pilosidade. Cerdas do escapo distribuídas da base até o ápice, exceto na face interna, na base aproximadamente tão longas quanto o diâmetro deste, um pouco mais curtas para o ápice (Fig. 23). Pedicelo com 4 cerdas eretas curtas, um pouco menores que o diâmetro deste; $1^{\circ} \mathrm{fl}$. com 2-3 cerdas eretas um pouco mais curtas que aquelas do pedicelo (Fig. 23). Área parocular inferior, um pouco abaixo dos alvéolos antenais, com algumas cerdas eretas, longas e robustas, ca. $2 \mathrm{x}$ mais 
longas que o diâmetro do $2^{\circ} \mathrm{fl}$,, sobressaindo-se à micropilosidade decumbente (Fig. 29); na área supra-clipeal e entre os alvéolos antenais, as cerdas eretas tão longas quanto aquelas do escapo. As cerdas eretas do clípeo, longas, duas delas próximas da base, ca. $2 \mathrm{x}$ mais longas que o diâmetro do $2^{\circ}$ fl. (Fig. 29); na fronte, mais curtas, tão longas quanto o diâmetro do $2^{\circ}$ fl.; no vértice, um pouco mais longas que aquelas do escapo; no escutelo, as cerdas eretas no bordo posterior, um pouco mais curtas que o comprimento deste.

\section{Integumento. Como descrito para o gênero.}

Forma e proporções (medidas na Tabela II). Cabeça 1,13x mais larga que longa e 1,28x mais larga que a distância clipeocelar. Olhos 2,24x mais longos que largos, paralelos. Área malar quase $2 \mathrm{x}$ mais longa que o diâmetro do $2^{\circ}$ fl. Clípeo $0,43 \mathrm{x}$ mais curto que sua largura máxima e $0,25 x$ a distância clipeocelar. Mandíbulas 0,54x a distância clipeocelar; com dois dentículos, separados por um recorte raso, o do canto interno arredondado (Fig. 13). Labro sem depressão mediana longitudinal. Escapo um pouco achatado na metade basal, alargado no quarto préapical e curvado no ápice (Fig. 23), tão longo quanto 1,05x a distância alveolocelar. O $1^{\circ}$ fl. curto, o comprimento ca. metade de sua largura (Fig. 23). Distância interocelar 1,04x maior que a ocelorbital e 2,67x o diâmetro do ocelo médio. Região adjacente ao sulco frontal, acima da carena frontal, bastante deprimida em relação ao restante da fronte. Escutelo $0,46 x$ mais curto que largo. Tíbia III quase tão longa, $0,93 \mathrm{x}$, quanto a largura da cabeça, e 3,65x mais longa que larga. Basitarso III 2,48x mais longo que largo; o canto póstero-distal em ângulo reto. Asa anterior ca. 2,36x mais longa que larga, e 2,01x mais longa que a largura máxima da cabeça. Veia M levemente arqueada (como na Fig. 37).

Material-tipo. Holótipo, operária, de "PERU, SM, TarapotoYurimaguas road km 20 'BIODIVERSIDAD' S0634/W7620, 950 masl February 2003, Rasmussen leg"; parátipos, 3 operárias, com a mesma etiqueta de procedência. $\mathrm{O}$ holótipo e 1 parátipo no MUSM, e 2 parátipos na RPSP.

Distribuição geográfica e hábitat. Conhecida apenas da localidade do tipo, Peru, San Martin.

\section{Nidificação. Desconhecida.}

Etimologia. O nome da espécie é uma homenagem ao povo Chachapoya, civilização pré-incaica, que viveu na região dos formadores dos rios Huallaga e Marañon, Departamento do Amazonas, Peru.

Discussão. A forma do escapo, fortemente curvado próximo ao ápice e achatado próximo a base, o $1^{\circ} \mathrm{fl}$. curto, e a fronte mais deprimida medianamente, permitem reconhecer $D$. chachapoya sp. nov. dentre todas as espécies de Dolichotrigona. A mandíbula bidentada e presença de cerdas longas e robusta na área parocular inferior, são características presentes também em $D$. rondoni $\mathbf{s p . ~ n o v . , ~ D . ~ t a v a r e s i ~} \mathbf{s p . ~ n o v . ,}$
D. browni sp. nov. e D. moratoi sp. nov., nestas, porém, o escapo não é curvado próximo ao ápice, $\mathrm{o} 1^{\circ} \mathrm{fl}$. é aproximadamente tão longo quanto largo, e a fronte é apenas moderadamente deprimida na região do sulco frontal.

Agradecimentos. Aos curadores e pesquisadores que emprestaram material para este estudo, especialmente Arturo Roig Alsina, pelo envio do tipo de Trigona martinezi, e William Overal e Orlando Tobias Silveira pelo envio do lectótipo de Melipona longitarsis. A Claus Rasmussen, pelo envio de diversos exemplares do Peru, Colin Favret pelo envio dos espécimens do Illinois Natural History Survey, e Alain Pauly, do Institut Royal des Sciences Naturelles de Belgique, pelo envio de exemplares de D. schulthessi da Nicarágua. A José Albertino Rafael, Augusto Loureiro Henriques e Márcio Luiz Oliveira pelo envio dos espécimens de Dolichotrigona da coleção do INPA. A Elder Morato e John Christopher Brown, pela coleta e doação de grande parte das abelhas coletadas no Acre e Rondônia, respectivamente. A José Amílcar Tavares, técnico do Depto. Biologia, FFCLRP/USP, pela preparação, triagem dos espécimens e atualização dos fichários sobre Meliponini e Menderson Mazucato, técnico aposentado pela mesma instituição, pela inestimável colaboração na coleta e preparação de grande parte do material da coleção Camargo, sediada no Depto. de Biologia, FFCLRP/ USP.

\section{REFERÊNCIAS}

Ayala, R. B. 1999. Revisión de las abejas sin aguijon de Mexico (Hymenoptera: Apidae: Meliponini). Folia Entomologica Mexicana 106: 1-123.

Bego, L. R.; R. Zucchi \& S. Mateus. 1991. Notas sobre a estratégia alimentar (cleptobiose) de Lestrimelitta limao Smith (Hymenoptera, Apidae, Meliponinae). Naturalia 16: 119-127.

Bernal, R. \& F. Ervik. 1996. Floral biology and pollination of the dioecious palm Phytelephas seemannii in Colombia: an adaptation to staphylinid beetles. Biotropica 28: 682-696.

Brèthes, J. 1920. Insectes du Pérou. Annales de la Sociedad Cientifica Argentina 89: 51-54.

Camargo, J. M. F. 1988. Meliponinae (Hymenoptera, Apidae) da coleção do "Istituto di Entomologia Agraria", Portici, Itália. Revista Brasileira de Entomologia 32: 351-374.

Camargo, J. M. F. 1989. Comentários sobre a sistemática de Meliponinae (Hymenoptera, Apidae). Anais do XIV Simpósio Anual da ACIESP, publ. $\mathrm{n}^{\circ}$ 68(suplemento): 41-61.

Camargo, J. M. F. \& J. S. Moure. 1988. Notas sobre os Meliponinae (Hymenoptera, Apidae) colecionados por Filipo Silvestri na bacia do rio da Prata. Revista Brasileira de Entomologia 32: 293314.

Camargo, J. M. F. \& S. R. M. Pedro. 1992. Systematics, phylogeny and biogeography of the Meliponinae (Hymenoptera, Apidae): a minireview. Apidologie 23: 509-522.

Camargo, J. M. F. \& S. R. M. Pedro. 2003. Meliponini Neotropicais: o gênero Partamona Schwarz, 1939 (Hymenoptera, Apidae, Apinae) - bionomia e biogeografia. Revista Brasileira de Entomologia 47: 311-372.

Carvalho, J. C. M.; P. E. Lima \& E. Galvão. 1949. Observações zoológicas e antropológicas na região dos formadores do Xingu. Publicações Avulsas do Museu Nacional do Rio de Janeiro 5: 1-48, 23 figs.

Cockerell, T. D. A. 1911. Descriptions and records of bees. - XXXVIII. Annals and Magazine of Natural History 8: 285-286.

Cockerell, T. D. A. 1934. Some African meliponine bees. Revue de Zoologie et de Botanique Africaines 26: 46-62.

Ducke, A. 1916. Enumeração dos Hymenopteros colligidos pela Commissão e Revisão das espécies de abelhas do Brasil. Commissão de Linhas Telegraphicas e Estrategicas de Matto Grosso ao Amazonas, publicação no. 35, annexo 5, Hist. Nat. Zool., Rio de Janeiro, Ministério da Agricultura, 177 p.+Figs. 13-25 + errata. 
Ducke, A. 1925. Die stachellosen Bienen (Melipona) Brasiliens. Nach morphologischen und ethologischen Merkmalen geordnet. Zoologische Jahrbücher Abteilung für Systematik, Geographie und Biologie der Tiere 49: 335-448+Figs.1-24, pls. 3,4 .

Friese, H. 1900. Neue Arten der Bienengattungen Melipona Ill. und Trigona Jur. Természetrajzi Füzetek 23: 381-391.

Friese, H. 1902. Neue Meliponiden. (Hym.). Zeitschrift für Systematische Hymenopterologie und Dipterologie 2: 382383.

Griswold, T.; F. D. Parker \& P. E. Hanson. 1995. The Bees (Apidae), p.650-691. In: P. E. Hanson \& I. D. Gauld (eds.). The Hymenoptera of Costa Rica. Oxford, UK, Oxford University Press, 893 p.

Michener, C. D. 1954. Bees of Panamá. Bulletin of the American Museum of Natural History 104: 1-175.

Michener, C. D. 1990. Classification of the Apidae (Hymenoptera). The University of Kansas Science Bulletin 54: 75-164.

Michener, C. D. 1997. Genus-group names of bees and supplemental family-group names. Scientific Papers, Natural History Museum, The University of Kansas 1: 1-118.

Michener, C. D. 1999. The corbiculae of bees. Apidologie 30: 67-74.

Michener, C. D. 2000. The Bees of the World. The Johns Hopkins University Press, Baltimore and London, xiv +913 p. +16 pls.

Michener, C. D. \& D. W. Roubik. 1993. Observations on the labium of meliponine bees (Hymenoptera: Apidae), p. 251-265. In: T. Inoue \& S. Yamane (eds.). Evolution of Insect Societies: Comparative Sociology of Bees, Wasps and Ants. Tokyo, Hakuhin-sha Publishing Co., $532 \mathrm{p}$.

Moure, J. S. 1944. Abejas del Perú. Boletin del Museo de Historia Natural "Javier Prado" 8: 67-75.

Moure, J. S. 1950. Contribuição para o conhecimento das espécies brasileiras de Hypotrigona Cockerell (Hymen. - Apoidea). Dusenia 1: 241-260.

Moure, J. S. 1951. Notas sôbre Meliponinae (Hymenopt. - Apoidea). Dusenia 2: 25-70.

Moure, J. S. 1961. A preliminary supra-specific classification of the Old World meliponine bees (Hymenoptera, Apoidea). Studia Entomologica 4: 181-242.

Nascimento, P. T. R. 1979. Catálogo de tipos entomológicos do Museu Goeldi. Hymenoptera. Boletim do Museu Paraense Emílio Goeldi, sér. Zoologia, 98: 1-18.

Nates-parra, G. 2001. Las abejas sin aguijón (Hymenoptera: Apidae: Meliponini) de Colombia. Biota Colombiana 2: 233-248.

Oliveira, M. L. \& E. F. Morato. 1994. Abelhas sem ferrão (Apidae, Meliponinae) do estado do Acre. Anais do Encontro sobre Abelhas, Ribeirão Preto, SP, 1: 291.

Pedro, S. R. M. \& J. M. F. Camargo. 2003. Meliponini neotropicais: o gênero Partamona Schwarz, 1939 (Hymenoptera, Apidae). Revista Brasileira de Entomologia 47: 1-117.

Pereboom, J. J. M. \& J. C. Biesmeijer. 2003. Thermal constraints for stingless bee foragers: the importance of body size and coloration. Oecologia 137: 42-50.
Roubik, D. W. 1983. Nest and colony characteristics of stingless bees from Panamá (Hymenoptera: Apidae). Journal of the Kansas Entomological Society 56: 327-355.

Roubik, D. W. 1992. Stingless bees: a guide to Panamanian and Mesoamerican species and their nests (Hymenoptera: Apidae: Meliponinae), p. 495-524. In: D. Quintero \& A. Aiello (eds.). Insects of Panama and Mesoamerica. Selected Studies, Oxford, UK, Oxford University Press, 692 p.

Roubik, D. W. 1993. Direct costs of forest reproduction, bee-cycling and the efficiency of pollination modes. Journal of Bioscience 18: $537-552$.

Roubik, D. W. 2000. The de-flowering of Central America: a current perspective. In: Proceedings of the Sixth International Conference on Apiculture in Tropical Climates, International Bee Research Association, Cardiff, Wales, p. 144-151.

Sakagami, S. F.; D. W. Roubik \& R. Zucchi. 1993. Ethology of the robber stingless bee, Lestrimelitta limao (Hymenoptera: Apidae). Sociobiology 21: 237-277.

Schwarz, H. F. 1932. The genus Melipona: the type genus of the Meliponidae or stingless bees. Bulletin of the American Museum of Natural History 63: 231-460+pls. 1-10.

Schwarz, H. F. 1934. The social bees (Meliponidae) of Barro Colorado Island, Canal Zone. American Museum Novitates 731: 1-23.

Schwarz, H. F. 1938. The stingless bees (Meliponidae) of British Guiana and some related forms. Bulletin of the American Museum of Natural History 74: 437-508 + pls. 52-62.

Schwarz, H. F. 1940. Additional species and records of stingless bees (Meliponidae) from British Guiana. American Museum Novitates 1078: $1-12$.

Schwarz, H. F. 1948. Stingless bees (Meliponidae) of the Western Hemisphere. Bulletin of the American Museum of Natural History 90: 1-546 + xvii.

Silveira, F. A.; G. A. R. Melo \& E. A. B. Almeida, 2002. Abelhas Brasileiras. Sistemática e Identificação. Belo Horizonte, 253 $\mathrm{p}$

Smith-pardo, A. H. 2003. A preliminary account of the bees of Colombia (Hymenoptera: Apoidea): present knowledge and future directions. Journal of the Kansas Entomological Society 76: 335-341.

Villas Bôas, O. \& C. Villas Bôas. 1994. A marcha para o oeste. A epopéia da expedição Roncador-Xingu. São Paulo, Editora Globo, 615 p.

Wille, A. 1965. A new species of stingless bee (Meliponini) from Costa Rica. Revista de Biologia Tropical 13: 139-141.

Wille, A. 1979. Phylogeny and relationships among the genera and subgenera of the stingless bees (Meliponinae) of the world. Revista de Biologia Tropical 27: 241-277.

Wille, A. \& L. C. Chandler. 1964. A new stingless bee from the tertiary amber of the Dominican Republic (Hymenoptera; Meliponini). Revista de Biologia Tropical 12: 187-195.

Zanella, F. C. V.; M. L. Oliveira \& M. C. Gaglianone. 2000. Standardizing lists of locality data for examined specimens in systematics and biogeography studies of New World taxa. Biogeographica 76: 145-160.

Recebido em 06.VIII.2004; aceito em 10.XI.2004 